\title{
MANAGEMENT OF ENDOCRINE DISEASE Secondary osteoporosis: pathophysiology and management
}

\author{
Faryal Mirza' and Ernesto Canalis ${ }^{1,2}$ \\ Division of Endocrinology and Metabolism, Departments of ${ }^{1}$ Medicine and ${ }^{2}$ Orthopaedic Surgery, UConn \\ Musculoskeletal Institute, UConn Health, 263 Farmington Avenue, Farmington, Connecticut 06030-5456, USA
}

\begin{abstract}
Osteoporosis is a skeletal disorder characterized by decreased mass and compromised bone strength predisposing to an increased risk of fractures. Although idiopathic osteoporosis is the most common form of osteoporosis, secondary factors may contribute to the bone loss and increased fracture risk in patients presenting with fragility fractures or osteoporosis. Several medical conditions and medications significantly increase the risk for bone loss and skeletal fragility. This review focuses on some of the common causes of osteoporosis, addressing the underlying mechanisms, diagnostic approach and treatment of low bone mass in the presence of these conditions.

\section{Introduction}

Osteoporosis is a skeletal disorder characterized by low bone mass and microarchitectural deterioration of the skeleton leading to bone fragility and a predisposition to fractures. Osteoporosis is a major cause of morbidity and mortality, particularly in post-menopausal women and older men. While the pathogenesis of the bone loss and skeletal fragility is not well understood, estrogen deficiency plays a role in both sexes. It is classified as primary osteoporosis when it occurs in post-menopausal women and in men in the absence of an underlying disease, and it is age-related. Secondary osteoporosis is defined as low bone mass with microarchitectural alterations in bone leading to fragility fractures in the presence of an underlying disease or medication (1).

Secondary osteoporosis can be present in pre- and post-menopausal women and in men. Up to $30 \%$ of post-menopausal women and $50-80 \%$ of men are found to have factors contributing to osteoporosis when

\section{Invited Author's profile}

F Mirza is Assistant Professor of Medicine, University of Connecticut School of Medicine. She specializes in the management of patients with metabolic bone disease, osteoporosis, diabetes, thyroid and pituitary disorders, and women's health issues.

\section{Invited Author's profile}

E Canalis is Professor, Departments of Orthopaedic Surgery and Medicine, UConn Health. The Canalis laboratory discovered the existence of skeletal growth factors and his interests center around growth factors and their antagonists, anabolic agents and the management of osteoporosis.

(c) 2015 European Society of Endocrinology Printed in Great Britain

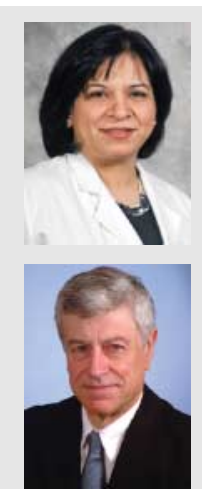

Published by Bioscientifica Ltd. 
undergoing an evaluation for underlying causes of the disease $(2,3)$. It is important to exclude secondary causes of osteoporosis as the treatment of these patients may differ, and its response may be limited if the underlying disorder is unrecognized and left untreated. For example, alendronate has a reduced efficacy in post-menopausal women with osteoporosis receiving thyroid-stimulating hormone (TSH)-suppressive doses of levothyroxine ( $\mathrm{L}-\mathrm{T}_{4}$ ) for the management of differentiated carcinoma of the thyroid (4). Similarly, gain in bone mineral density (BMD) is greater in post-menopausal women with hypercalciuria receiving a bisphosphonate along with indapamide to treat the hypercalciuria, than in patients receiving a bisphosphonate alone (5). Some of the common conditions associated with osteoporosis and increased risk of fractures are listed in Table 1. Certain drugs may also increase the risk of bone loss and fractures (Table 2), and bone health issues should be considered when prescribing these medications.

In this review, common causes of secondary osteoporosis and the underlying mechanisms of bone loss are presented. Genetic conditions that directly affect the skeleton, such as osteogenesis imperfecta, are associated with an increased risk of fractures and were recently reviewed in the journal, so they are not included in this review (6).

Table 1 Common diseases associated with osteoporosis.

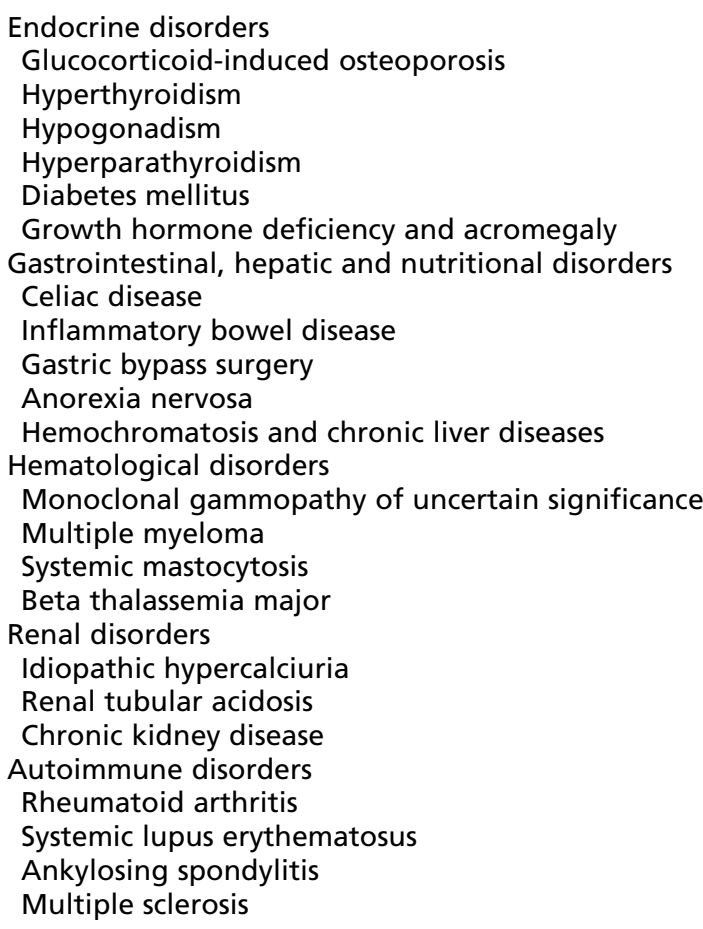

\section{Endocrine causes of osteoporosis}

Glucocorticoid-induced osteoporosis $>$ Glucocorticoidinduced osteoporosis (GIO) is the most common form of secondary osteoporosis. Although endogenous hypercortisolism or Cushing's syndrome can be associated with bone loss, most of the patients suffering from GIO receive glucocorticoids for the treatment of a variety of diseases. A fundamental point to recognize is that glucocorticoids are often administered to patients with inflammatory and autoimmune disorders, and the underlying disease itself is frequently a cause of osteoporosis. Inflammatory bowel disease (IBD), rheumatoid arthritis (RA) and systemic lupus erythematosus (SLE) are associated with bone loss due to the systemic release of inflammatory cytokines with significant effects on bone remodeling. In fact, older women with high inflammatory burden are at an increased risk of hip fractures (7). Glucocorticoid administration itself is associated with side effects, including osteoporosis and their use is characterized by a significant increase in fractures. Approximately 250000 men and women take long-term glucocorticoids in the UK and are at a significantly increased risk of osteoporotic fractures and hip fractures independent of prior fractures (8). The cumulative dose and duration of glucocorticoid exposure are determinants of the risk of fractures (9). However, prolonged exposure to doses of prednisolone as low as $2.5-5 \mathrm{mg}$ daily are associated with an increased risk of hip and vertebral fractures; a risk that increases with higher doses of prednisolone (10). Pre-menopausal women are protected, to some extent, from the detrimental actions of glucocorticoids on the skeleton, and post-menopausal women are at a greater risk of fractures. Indeed, no fractures were observed in pre-menopausal women in the alendronate intervention trial in either placebo or alendronate treated subjects with GIO (11). This may be because pre-menopausal women have a healthier skeleton than post-menopausal women when started on glucocorticoids. Importantly, the risk of fractures following intermittent glucocorticoids is modest and the risk decreases after discontinuation of glucocorticoids, suggesting that short-term exposure to these steroids does not have major detrimental effects on bone structure (12). Inhaled glucocorticoids have minimal effects on bone metabolism due to their limited absorption (13).

Glucocorticoids have both direct and indirect effects on bone metabolism (14). By blocking vitamin D actions on calcium absorption, glucocorticoids may cause transient decreases in serum calcium and modest increases in the serum levels of parathyroid hormone (PTH).

www.eje-online.org 
Table 2 Drug-induced osteoporosis.

Hormones and drugs with actions on the endocrine system
Glucocorticoids
Thyroid hormone
Hypogonadism-inducing agents
Aromatase inhibitors
Medroxyprogesterone acetate
GnRH agonists
Thiazolidinediones
Drugs with actions on the CNS
Antidepressants
Anticonvulsants
Drugs with actions on the immune system
Calcineurin inhibitors
Antiretroviral therapy
Anticoagulants; heparin
Diuretics: loop diuretics
Drugs with actions on the gastrointestinal tract
Proton pump inhibitors

However, secondary hyperparathyroidism does not explain the bone loss following glucocorticoid treatment, and serum PTH levels are not in the hyperparathyroid range. During the period of initial exposure to glucocorticoids, there is an increase in bone resorption, which is most likely responsible for a rapid decline in BMD and initial increase in fracture risk. The mechanism by which glucocorticoids enhance bone resorption is an induction of receptor activator of NF-KB ligand (RANKL) and of macrophage stimulating factor (MCSF), both required for osteoclastogenesis, and a decrease in the RANKL decoy receptor osteoprotegerin (OPG) (15). Glucocorticoids, however, may inhibit osteoclast bone degrading capacity and disruption of glucocorticoid receptor in osteoclast precursors not only reverses these effects of glucocorticoids but also protects from their inhibitory effects on bone formation (16). As skeletal exposure to glucocorticoids continues, bone formation is suppressed and a state of decreased bone remodeling ensues. The mechanism involves direct effects of glucocorticoids on cells of the osteoblastic lineage; cell number decreases because of an inhibition of osteoblast precursor cell replication and differentiation, and an increase in osteoblast apoptosis. In the presence of glucocorticoids, mesenchymal cells are directed toward cells of the adipocytic lineage instead of toward osteoblasts (17). A mechanism by which glucocorticoids inhibit osteoblast cell differentiation is by opposing Wnt/ $\beta$-catenin, and Wnt is a critical regulator of osteoblastogenesis and also an inhibitor of bone resorption $(18,19)$.

Glucocorticoids not only deplete the osteoblast cell population but also inhibit mature osteoblast function directly, and indirectly by suppressing the expression of insulin-like growth factor 1 (IGF1) by skeletal cells $(20,21,22)$. Glucocorticoids decrease the secretion of growth hormone (GH) and may alter the GH/IGF1 axis and also inhibit the release of gonadotropins, and as a result decrease estrogen and testosterone production and cause hypogonadism and bone loss $(23,24)$. Osteocytes are mechanosensors that play a role in the repair of bone microdamage, and glucocorticoids induce their apoptosis (22).

11 Beta-hydroxysteroid dehydrogenases (11ß-HSDs) are isoenzymes that catalyze the interconversion of hormonally active cortisol and inactive cortisone and can regulate glucocorticoid activity (25). 11ß-HSD1, a low affinity NADPH-dependent enzyme, is a bidirectional dehydrogenase/reductase, although it displays primarily reductase activity, converting cortisone to cortisol (26). $11 \beta$-HSD1 is widely expressed in glucocorticoid target tissues, including adult bone, and activates inactive glucocorticoids to facilitate glucocorticoid action. Glucocorticoids enhance 11 $\beta$-HSD1 mRNA expression and activity in human osteoblasts and non-skeletal cells, and the effect could result in the amplification of the cellular actions of glucocorticoids in osteoblasts, where the enzyme may act as a positive autoregulator of glucocorticoid action $(27,28,29)$.

Fractures in the context of GIO occur frequently at sites rich in cancellous bone, such as vertebrae and femoral neck, and vertebral fractures are often asymptomatic (30). A direct relationship between BMD and fracture risk in GIO has not been established, and post-menopausal osteoporosis diagnostic criteria should not be applied to GIO. Indeed, fractures in the context of glucocorticoid exposure occur at higher BMD values than in postmenopausal osteoporosis, and therapeutic intervention should be considered at $T$-scores that are in the osteopenic range $(31,32)$. FRAX, a computer algorithm that calculates the 10-year probability of major osteoporotic and hip fractures, can be used to estimate fracture risk in GIO. However, its value is limited by the fact that the use of glucocorticoids is entered as a dichotomous risk factor without consideration to the dose or length of exposure to glucocorticoids. Ways to correct for this limitation have been proposed, but their value has not been fully tested $(8,33)$. Changes in biochemical markers of bone turnover are dependent on the stage of the disease and have limited diagnostic value. Following high dose administration of i.v. glucocorticoids, there is an early and persistent decrease in bone formation markers and a transient increase in bone resorption markers (34). 
Markers of bone formation such as serum osteocalcin also are suppressed in patients with endogenous Cushing's syndrome (35).

Administration of supplemental calcium and vitamin $\mathrm{D}$, use of the minimal effective dose of gucocorticoids to control the underlying disease and lifestyle changes are all recommended in the management of $\operatorname{GIO}(31,36)$. Glucocorticoids oppose the effects of vitamin D on calcium absorption, although the mechanisms are poorly understood. In vitro studies have shown that glucocorticoids can increase or decrease the expression of the vitamin D receptor, suggesting that other mechanisms may be responsible for these effects of glucocorticoids $(37,38)$. Subjects receiving glucocorticoids may require higher doses of vitamin $\mathrm{D}_{3}$ daily, but calcium and vitamin D supplementation alone may not prevent the detrimental effects of glucocorticoids on the skeleton (39).

Bisphosphonates are indicated for the prevention and treatment of GIO, and teriparatide is indicated for the treatment of the disease. Alendronate, risedronate and zoledronic acid prevent the early decline in BMD in GIO and increase BMD in patients with established GIO $(11,40)$. However, evidence of reduction in vertebral fractures is only available for risedronate and benefit at non-vertebral sites was demonstrated only in observational studies (41). This is in part due to the fact that incidence of fractures was not a primary endpoint of the studies testing drug efficacy in GIO (33). Bisphosphonates are beneficial since there is a period of increased bone resorption following exposure to glucocorticoids, and their administration serves to stabilize BMD. Their use in pre-menopausal women needs to be considered with caution, since they cross the placenta and may affect embryonic skeletal development. Teriparatide is an option for the treatment of GIO since glucocorticoids have pronounced negative effects on osteoblast differentiation and function, and teriparatide is more effective than alendronate in increasing BMD at the lumbar spine and total hip (42). Although not a trial endpoint, subjects in the teriparatide arm had substantially less fractures than subjects in the alendronate arm (42).

Hyperthyroidism, thyroid hormone replacement and suppressive therapy Euthyroidism is essential for normal skeletal development and linear growth and for the attainment of peak bone mass in early adulthood. Thyroid hormone deficiency in children results in impaired skeletal development and delayed bone age, while hyperthyroidism is associated with accelerated skeletal development and advanced bone age (43). Both hyperthyroidism and hypothyroidism have been associated with osteoporosis and increased risk of fractures. Thyrotoxicosis results in an increase in bone turnover, shortening of the bone remodeling cycle and uncoupling of bone remodeling, and can cause a loss of up to $10 \%$ of mineralized bone per remodeling cycle, while hypothyroidism can lengthen the bone remodeling cycle (44).

Suppressed serum TSH and a history of hyperthyroidism are associated with an increased risk of hip and vertebral fractures $(45,46,47)$. In addition, ongoing therapy with thyroid hormone replacement is inversely correlated with BMD and increases the risk of fractures even in the presence of euthyroidism (48). TSH also has direct effects on the osteoclasts and osteoblasts (49). However, low BMD in peri-menopausal women seems to be dependent on serum levels of free thyroid hormones (50).

Several factors including age and sex of the patient, duration of treatment with $\mathrm{T}_{4}$ and the presence of additional predisposing factors may influence the impact of thyroid status on the skeleton, with older postmenopausal women being at the greatest risk for bone loss $(45,51,52,53)$. There are no specific guidelines for the prevention of bone loss secondary to hyperthyroidism. Supplemental calcium and vitamin D should be administered; and because thyroid hormone increases bone remodeling, antiresorptive agents may be considered in post-menopausal women at an increased risk of fractures.

\section{Hypogonadism and agents inducing hypogonadism -} Hypogonadism is associated with bone loss in men and women. It is the main underlying physiological change in post-menopausal women associated with low BMD and idiopathic osteoporosis. Premature menopause and medications, such as aromatase inhibitors and gonadotropin-releasing hormone $(\mathrm{GnRH})$ analogs which cause hypogonadism, are associated with low BMD and increased risk of fractures. The effect of estrogen deficiency related to menopause and its contribution to postmenopausal osteoporosis is beyond the scope of this review which focuses on secondary causes of the disease. Hypogonadism is the most common cause of osteoporosis in men and is present in up to $20 \%$ of men with symptomatic vertebral fractures and $50 \%$ of elderly men with hip fractures (54). Both primary hypogonadism and testosterone deficiency due to androgen deprivation therapy are associated with an increased risk of osteoporosis and fractures $(54,55,56)$. Men with osteoporosis may present either with symptomatic or asymptomatic hypogonadism and low serum levels of free testosterone. 
Androgens have dual effects on the skeleton; a direct effect through activation of the androgen receptor and an indirect effect, following their aromatization to estrogen, which then signals through activation of estrogen receptor alpha $(\mathrm{ER} \alpha)$. In men, the testes account for $\sim 15 \%$ of circulating estrogens and the remaining $85 \%$ is derived from peripheral aromatization of circulating androgen precursors in peripheral tissues. Both androgens and estrogens influence bone resorption in men independently. Androgens also regulate bone formation in men as shown in a study of young transgender men where testosterone treatment resulted in a significant increase in bone formation markers and hip BMD with no significant changes in estradiol $\left(\mathrm{E}_{2}\right)$ levels, suggesting that this effect of testosterone was independent of its aromatization to estrogens (57).

Testosterone and $5 \alpha$-dihydrotestosterone regulate gene expression in osteoblasts and inhibit the resorptive capacity of isolated human and murine osteoclasts in vitro $(58,59)$. In addition, sex hormones influence the secretion of a variety of cytokines and growth factors from skeletal cells including MCSF, and the proinflammatory molecules interleukin 1 (IL1), IL6 and tumor necrosis factor alpha (TNF $\alpha$ ), RANKL and OPG, which contribute to the effects of androgens on bone remodeling $(58,60,61)$.

Androgen replacement therapy in hypogonadal men with osteoporosis results in an increase in BMD, and the greatest increase is typically observed during the first year of therapy (62). As a consequence, androgen replacement therapy may be used in symptomatic patients to control hypogonadal symptoms as well as the skeletal manifestations of hypogonadism. Bisphosphonates are effective in the treatment of male osteoporotic patients with or without hypogonadism (63). Higher RANKL levels have been reported with low testosterone levels, and the RANKL antibody denosumab is effective in the treatment of men with osteoporosis $(64,65)$.

Aromatase inhibitors $>$ Aromatase inhibitors are used in the management of ER positive breast cancer and act by inhibiting the aromatization of androgens, resulting in lower estrogen levels and bone loss. Anastrazole and letrozole are non-steroidal aromatase inhibitors while exemestane is a steroid that binds aromatase irreversibly (66). Aromatase inhibitors are effective in the treatment of infertility in polycystic ovarium syndrome, although no adverse skeletal effects should be expected following the short duration of exposure for infertility treatment of premenopausal women $(66,67)$. In most trials, the effectiveness and adverse event profile of aromatase inhibitors are compared to tamoxifen. Aromatase inhibitors increase biochemical markers of bone turnover, decrease BMD and increase the risk of fractures when compared to tamoxifen $(68,69,70)$. Bisphosphonates and denosumab increase BMD in patients treated with aromatase inhibitors, but data on fracture reduction efficacy following antiresorptive therapy are limited.

Medroxyprogesterone acetate $\boldsymbol{D}$ Depot medroxyprogesterone acetate is an injectable progestogen used as a contraceptive agent and in the treatment of endometriosis. Medroxyprogesterone acetate inhibits gonadotropin secretion, suppressing ovulation and estrogen production by the ovary; and as a consequence, it causes a decrease in BMD. This is reversible following the discontinuation of medroxyprogesterone, and whether there is an increase in the risk of fractures is not established (71).

GnRH agonists $\downarrow$ GnRH agonists are analogs with increased receptor affinity or prolonged half-lives that lead to persistent activation of GnRH receptors and suppression of gonadotropin secretion, with a consequent decrease in ovarian estrogen production. GnRH agonists are effective in the management of endometriosis and infertility in premenopausal women. By suppressing estrogen levels, they cause a decline in BMD; this is reversed following the discontinuation of the GnRH agonist $(72,73)$.

GnRH agonists are used as androgen deprivation therapy in patients with advanced carcinoma of the prostate. GnRH analogs reduce serum testosterone and $\mathrm{E}_{2}$ levels and increase bone turnover causing bone loss and increasing the risk of fractures $(74,75,76,77,78)$. Men undergoing androgen deprivation therapy as part of the management of prostate cancer suffer $2-8 \%$ loss of vertebral BMD and 2-6\% loss of BMD at the femoral neck compared to age-matched controls. The greatest decline in BMD occurs in the first year following initiation of androgen deprivation therapy and is associated with a significant decrease in sex steroid hormone levels and with an increase in bone turnover markers $(79,80)$.

Treatment is recommended for patients with osteoporotic fractures or with significant risk factors for fractures (81). Calcium and vitamin D are indicated. Bisphosphonates are effective in restoring BMD in patients suffering from bone loss secondary to androgen deprivation therapy, but data on fracture reduction are limited $(80,82)$. Selective ER modulators, such as raloxifene and toremifene, have beneficial effects on BMD, but are not approved for use in men $(83,84)$. Denosumab can prevent 
bone loss and reduces the incidence of vertebral fractures in men receiving androgen deprivation therapy (85).

Hyperparathyroidism $>$ Primary hyperparathyroidism (PHPT) is associated with an increase in the expression of RANKL by cells of the osteoblast lineage and an increase in osteoclast-mediated bone resorption. Although osteoblast activity and bone formation may increase, this is not sufficient to counteract the enhanced bone resorption. Bone turnover markers are normal or mildly elevated. PHPT is associated with cortical bone loss, so that BMD in the distal forearm and the hip are decreased, although trabecular bone may also be affected in PHPT $(86,87)$. There is an increased risk of vertebral, wrist, ankle, rib and pelvic fractures in PHPT $(88,89)$. Parathyroidectomy results in normalization of serum calcium levels and an increase in vertebral and femoral BMD. Bisphosphonates and hormone replacement therapy decrease bone remodeling and increase BMD in patients with PHPT (90). However, fracture data are not available and neither agent lowers serum calcium or PTH levels. Denosumab can correct the hypercalcemia of PHPT and has been used effectively in the treatment of hypercalcemia in patients with parathyroid carcinoma $(91,92,93,94,95)$.

Diabetes mellitus • Diabetes mellitus (DM) and impaired glucose metabolism have a detrimental effect on bone metabolism, and both types 1 and 2 DM carry increased risk of fractures; the risk is higher with type 1 than with type $2 \mathrm{DM}(96,97)$. The risk for fractures is common to both men and women, and increases with the duration of the disease and the use of insulin $(97,98)$.

Although type $2 \mathrm{DM}$ is associated with an increase in BMD associated with higher insulin and IGF1 levels, there is a higher occurrence of fractures in this population. As fractures occur at higher bone density in diabetics than in non-diabetic patients, BMD cannot predict the risk for fractures accurately in this population (99). In preliminary studies, trabecular bone score was shown to predict fracture risk in diabetic patients, but its use needs further validation (100). It is important to consider fracture prevention strategies at a relatively earlier stage in patients with DM. Diabetic patients should be counseled on adequate calcium and vitamin D intake, and glycemic control should be optimized to minimize microvascular complications, retinopathy and neuropathy, which may lead to an increased risk of falls and fractures.

Agents that have been used for the treatment of DM, such as thiazolidinediones, are associated with an increased risk of fractures. Thiazolidinediones are insulin-sensitizing drugs that activate peroxisome proliferator-activated receptor gamma, a transcription factor that controls mesenchymal cell allocation by increasing adipogenesis and decreasing osteoblastogenesis $(17,101,102)$. Thiazolidinediones also promote osteoclast differentiation and bone resorption, and patients may experience bone loss and low BMD $(103,104,105)$.

GH deficiency and acromegaly $\bullet$ GH plays an important role in linear growth and attainment of appropriate height and peak bone mass during childhood and adolescence (106). GH increases bone formation by interacting directly with GH receptors on osteoblasts and via locally produced IGF1. GH deficiency (GHD) has been associated with delayed skeletal maturation and low BMD in patients with isolated GHD as well as in patients with multiple pituitary deficiencies, predominantly through decreased bone formation (107). Several studies have reported a higher prevalence of osteoporosis and a higher fracture rate in adult onset GHD and morphometric vertebral fractures have been reported in up to half of patients with GHD (108). Treatment of GHD with GH increases vertebral and femoral BMD over time. Recombinant human GH has a biphasic effect on bone; an initial phase associated with an increase in bone resorption and a decrease in BMD and a second phase characterized by an increase in bone formation and in BMD, usually after 6-12 months of treatment (109).

Acromegaly is associated with increased bone remodeling, and patients with acromegaly have a significantly higher prevalence of vertebral fractures, which correlate with the duration of the disease and serum IGF1 levels $(109,110)$. Radiological vertebral fractures occur in as many as a third of the patients with acromegaly without changes in BMD, so that BMD has limited value in the assessment of these patients. A formal vertebral morphometric analysis is recommended in patients with acromegaly to evaluate for the presence of occult vertebral fractures. Although treatment of acromegaly improves bone health, the increased risk of fractures may persist in patients with hypogonadism and with prior history of vertebral fractures (111).

\section{Gastrointestinal, nutritional and hepatic causes of osteoporosis}

Celiac disease $\bullet$ Celiac disease is associated with bone loss and an increased risk of fractures. About one-third of patients with celiac disease have osteoporosis, with men being more severely affected than women (112). In children, celiac disease is associated with delayed bone 
growth and puberty due to nutritional deficiency and malabsorption (113). Both symptomatic and asymptomatic patients with celiac disease have low BMD, and tissue transglutaminase antibody IgA seropositivity status is associated with osteoporosis and increased risk of hip fractures $(114,115)$. Decreased calcium absorption, the consequent secondary hyperparathyroidism and an increase in the levels of inflammatory cytokines, including TNF $\alpha$, IL1 and IL6, may be responsible for an increase in bone resorption $(116,117)$. Malabsorption of micronutrients may contribute to altered bone metabolism.

Institution and long-term adherence to a gluten free diet improves BMD in children and adults, although BMD is seldom normalized. There is no agreement on when to obtain BMDs in patients with celiac disease, and its value to predict fracture risk has also not been established in this disease (116). There are no longitudinal studies evaluating the efficacy of bisphosphonates in celiac disease, although their use is common when patients manifest osteoporosis. Gluten free diet and optimal calcium and vitamin D supplementation should be initiated.

Inflammatory bowel disease $\rightarrow$ IBD is comprised by Crohn's disease and ulcerative colitis, and both are associated with osteoporosis. The prevalence of osteoporosis varies and is related to the severity of the IBD and related comorbid conditions. Osteoporosis can present in more than one-third of patients with established IBD and is associated with an increased frequency of vertebral and hip fractures $(118,119)$. Children with IBD may fail to achieve peak bone mass (120). The mechanisms responsible for the bone loss in IBD include disease-related inflammatory activity and treatment-related side effects, including glucocorticoid therapy, nutritional deficiencies, leading to low BMI and contributing to hypogonadism. Disease severity correlates with fracture risk even after adjusting for corticosteroid use. The risk of fractures is higher in Crohn's disease than in ulcerative colitis (121).

Serum levels of the pro-inflammatory cytokines $\mathrm{TNF} \alpha$, IL1 $\beta$, IL6 and IL17 are increased in IBD $(122,123)$. These cytokines enhance osteoclastogenesis and bone resorption and inactivation of the TNF type 1 receptor abrogates the effect of $\mathrm{TNF} \alpha$ on osteoclastogenesis in bone marrow macrophage cultures, suggesting that increased TNF production contributes to the bone loss found in patients with IBD $(124,125)$. This is substantiated by studies demonstrating that treatment of patients with IBD with the anti-TNF $\alpha$ antibody infliximab improves vertebral BMD (126).
Ongoing treatment with glucocorticoids contributes to the bone loss and increased risk of fractures (127). In prospective studies in children and adolescents, greater lifetime prednisolone exposure correlates with lower lumbar spine BMD, reflecting both a more active disease and the effects of glucocorticoids $(120,128,129)$.

Vitamin D deficiency is common in patients with Crohn's disease, particularly in patients with prior ileal resection $(130,131)$. Lower calcium intake and absorption, as well as vitamin $\mathrm{K}$ nutritional deficiencies, may contribute to the bone loss (132).

Patients with IBD should be evaluated for osteoporosis, and calcium and vitamin D intake need to be optimized. Patients should be maintained on the lowest dose of glucocorticoids needed to maintain the disease in remission, and antiresorptive therapy should be used in patients with osteoporosis and fractures.

Gastric bypass surgery $>$ In the past decade, there has been an increase in the number of cases undergoing bariatric surgery, a surgical procedure associated with bone loss. The surgical technique used may play a role in the bone loss. Osteoporosis and osteomalacia, resulting from defective mineralization are long-term complications of gastrectomy. Surgical techniques that result in malabsorption lead to malnutrition, calcium and vitamin D deficiency with consequent secondary hyperparathyroidism, all of which contribute to bone loss. Vitamin D supplementation is recommended in these patients.

Although there is a higher prevalence of osteopenia and vertebral fractures in patients following gastric bypass surgery, the exact risk for osteoporosis and fractures is unknown (133). Patients undergoing bypass surgery have low BMD, but there are technical limitations of the dual energy X-ray absorptiometry technology in this population due to the weight of the patients. There is a lack of long-term prospective data on BMD in this patient population. Therefore, it is difficult to determine the impact of the surgery on BMD.

Eating disorders $>$ Anorexia nervosa is associated with significant weight loss, hypogonadotropic hypogonadism with amenorrhea, low BMD and an increased risk of fractures (134). Both cortical and trabecular bone are affected, bone accrual during growth is slow and peak bone mass is low. Serum markers of bone formation are suppressed and markers of bone resorption are increased suggesting that bone formation is uncoupled from bone resorption. The best strategy to improve bone health is to regain weight and ovarian function. Oral estrogen- 
progesterone combinations are not effective in increasing BMD in adults or adolescents with anorexia nervosa. However, physiological estrogen replacement as transdermal $E_{2}$ with cyclic progesterone increase bone accrual rates in adolescents with anorexia nervosa, leading to maintenance of BMD. Risedronate also increases vertebral and hip BMD, but bisphosphonates should be used with great caution in women of reproductive age, given the long half-life of bisphosphonates and potential for teratogenicity (135).

Hemochromatosis and other chronic liver diseases Hemochromatosis is a relatively common genetic disorder, which results in iron overload and iron deposition in several tissues including the liver, pancreas and the pituitary gland. Osteoporosis can be prevalent in onequarter to one-third of patients with hemochromatosis (136). Several factors contribute to osteoporosis in patients with hemochromatosis including secondary hypogonadism, liver failure and vitamin D deficiency. Iron also has direct toxic effects on the skeleton, resulting in increased bone resorption and decreased bone formation (137). It is not known whether the treatment of hemochromatosis restores skeletal architecture or BMD. At present, guidelines for post-menopausal and male osteoporosis are recommended for the management of osteoporosis in these patients.

Metabolic disturbances of bone are associated with chronic liver diseases particularly those affected by cholestasis, such as primary biliary cirrhosis and primary sclerosing cholangitis (138). The mechanisms responsible for osteoporosis in chronic liver disease are complex and include malnutrition, glucocorticoid use, vitamin D deficiency and hypogonadism, as well as complications that follow liver transplantation (138). Patients with end stage liver disease are at significant risk of bone loss and $40-60 \%$ present with BMD in the osteopenic or osteoporotic range and nearly $25 \%$ suffer fragility fractures of the spine or ribs (139). The prevalence of osteoporosis/osteopenia in patients with primary biliary cirrhosis is $20-40 \%$ depending on the stage of the disease; and about $10-20 \%$ of this patient population presents with fragility fractures $(140,141)$. Management consists of decreasing risk factors and possible anti-fracture intervention, although data on the efficacy of therapeutic intervention in chronic liver disease are limited. There is evidence that bisphosphonates increase BMD in patients with chronic liver disease, but the number of patients studied is too limited to demonstrate anti-fracture efficacy $(142,143,144)$.

Hepatitis C is a common form of hepatitis, and 5-20\% of patients will progress to develop cirrhosis (145).
However, even in the absence of cirrhosis, patients with chronic hepatitis $\mathrm{C}$ infection present with osteopenia or even osteoporosis, as defined by low BMD $(146,147)$. The mechanisms responsible have not been established, although chronic inflammation may play a role. There is no apparent increase in the incidence of fractures in patients with hepatitis $\mathrm{C}$ infection without cirrhosis and some studies have reported normal BMD in wellnourished patients with hepatitis C infection $(147,148)$. However, hepatitis $\mathrm{C}$ infection may contribute to the risk of fractures among patients with human immunodeficiency virus (HIV) infections (149).

\section{Hematological disorders and osteoporosis}

Monoclonal gammopathy of uncertain significance Monoclonal gammopathy of uncertain significance (MGUS) is characterized by an overproduction of monoclonal protein and an imbalance in bone remodeling that leads to diffuse bone loss. MGUS and multiple myeloma are common causes of osteoporosis associated with fragility fractures. MGUS is characterized by a plasma cell content of $<10 \%$ in the bone marrow, a monoclonal (M) protein spike of $\leq 30 \mathrm{~g} / \mathrm{l}$ and no end organ damage (absence of skeletal lytic lesions, hypercalcemia, renal insufficiency, anemia and bone lesions) (150).

MGUS patients are at increased risk for osteoporosis, vertebral and hip fractures, and a higher prevalence of MGUS is found in patients older than 50 years of age who present with hip fractures (151, 152, 153, 154, 155). Typically, MGUS is associated with increased bone resorption and reduced bone formation, and the Wnt antagonists, Dickkopf-1 (Dkk-1), soluble frizzled related proteins 2 and 3 and sclerostin have been associated with skeletal disease and bone loss $(156,157,158,159,160,161)$. Wnt signaling enhances osteoblast differentiation and suppresses osteoclastogenesis, thereby contributing to the maintenance of bone mass. Interference of Wnt signaling by Wnt antagonists and an increase in RANKL by inflammatory cytokines contribute to the bone loss in MGUS (162).

Current guidelines do not recommend the use of bisphosphonates in patients with MGUS. Alendronate and zoledronic acid cause a significant increase in BMD in patients with MGUS, but no data are available on fracture risk reduction by these agents $(163,164)$.

Multiple myeloma $\rightarrow$ Multiple myeloma is a plasma cell disorder, characterized by bone marrow infiltration with clonal plasma cells, production of monoclonal immunoglobulin and end organ damage including lytic lesions 
in bone with hypercalcemia, renal impairment and bone marrow involvement with anemia. The clonal proliferation results in classic lytic lesions and reduced bone mass due to increased bone resorption and decreased bone formation. Myeloma cells achieve these effects through the production of several cytokines, such as IL6 and IL7, leading to an increase in RANKL production by bone marrow stromal cells and an increased degradation of OPG. This results in an increased RANKL/OPG ratio, the differentiation of osteoclast precursors and enhanced bone resorption $(165,166)$. The expression of the Wnt antagonists, Dkk-1 and secreted frizzled protein-2, are increased in myeloma explaining the decrease in osteoblastogenesis through an inhibition of Wnt signaling $(159,167)$. The net effect of these changes is decreased bone formation and increased bone resorption, leading to osteoporosis. Bisphosphonates and targeted therapies for myeloma help reduce osteolysis and the risk of fractures (168). Denosumab may be an alternative for the prevention of skeletal-related complications in patients with multiple myeloma with impaired renal function since the drug is not metabolized or excreted by the kidneys (169).

Systemic mastocytosis — Systemic mastocytosis is a hematologic condition commonly associated with reduced bone mass and osteoporosis, and is present in $\sim 9 \%$ of bone biopsies from men with idiopathic osteoporosis (170). Vertebral compression fractures are relatively common in men and women with systemic mastocytosis (171). Generally, there is greater bone loss at the spine than at the hip. Spine X-rays and BMD are warranted in patients with or without skin involvement and particularly in males. Diagnosis is based on an elevated serum tryptase level and increased 24-h urine excretion of $\mathrm{N}$-methylhistamine, but diagnosis requires histologic confirmation demonstrating mast cell infiltration in the bone marrow as well as the finding of $c-K I T$ mutations. Systemic mastocytosis is frequently associated with mutations of the KIT receptor tyrosine kinase (c-KIT), leading to the constitutive activation of c-KIT in most cells (172). Therefore, genetic analysis of $c$-KIT in patients with mastocytosis can be of diagnostic value.

The proximity of the mast cell to bone remodeling surfaces and the production of chemical mediators and cytokines, such as histamine, prostaglandins, leukotrienes and cytokines (IL1, IL3 and IL6) contribute to the skeletal pathology (173). Patients have higher levels of IL6 and RANKL leading to an increase in bone resorption and higher levels of serum sclerostin possibly contributing to a decrease in Wnt signaling and bone formation (174).
However, the mechanisms responsible for osteoporosis and increased fracture risk need further study so that targeted therapies can be evaluated. Bisphosphonates such as alendronate, pamidronate and zoledronic acid can improve BMD and decrease bone resorption in patients with mastocytosis $(175,176)$.

Beta thalassemia major $\downarrow$ Thalassemias comprise a group of inherited disorders of hemoglobin synthesis, and mutations in the BGLOBIN gene lead to defective $\beta$ globin production and anemia. The care of these patients with transfusions and iron chelation has improved patient survival; and as a result, thalassemia major is now associated with osteoporosis. This is a prominent cause of morbidity among affected patients (177). The etiology of the osteoporosis is multifactorial. Enhanced bone resorption and remodeling and suppressed osteoblastic function with bone loss and increase risk of fractures occur in patients affected with thalassemia major. Bisphosphonates decrease bone remodeling and increase BMD in patients with thalassemia major, although it is not known whether fracture risk is decreased with bisphosphonate therapy (178).

\section{Renal causes of secondary osteoporosis}

Idiopathic hypercalciuria $>$ Idiopathic hypercalciuria is associated with a 24-h urinary calcium excretion in excess of $4 \mathrm{mg} / \mathrm{kg}$ in women or of $4.5 \mathrm{mg} / \mathrm{kg}$ in men without an underlying cause. Idiopathic hypercalciuria is associated with low BMD and an increased prevalence of fractures, as calcium excretion is higher than absorption, resulting in a net calcium loss. In the Third National Health and Nutrition Examination Survey, men with a history of kidney stones were found to have lower femoral neck BMD, elevated markers of bone turnover and an increased risk of wrist and vertebral fractures $(179,180,181)$. IL1, IL6 and $\mathrm{TNF} \alpha$ are increased in hypercalciuria and are associated with elevated markers of bone turnover (182).

The bone loss associated with idiopathic hypercalciuria may be caused by a primary disorder of bone formation or resorption, or may be secondary to the abnormal renal handling of calcium and sodium. The underlying mechanisms of the bone loss are not entirely known. Idiopathic hypercalciuria is characterized by increased intestinal calcium absorption, increased bone resorption and decreased renal tubular calcium reabsorption (180). Higher circulating 1,25-dihydroxyvitamin $\mathrm{D}_{3}$ levels and an increased expression of the vitamin D receptor in monoctyes occur in the majority of patients 
with hypercalciuria and renal stones $(183,184)$. Studies in genetic hypercalciuric stone forming rats show a decrease in urinary calcium excretion with bisphosphonates, suggesting that the increase in urinary calcium is secondary to enhanced bone resorption (185).

Patients with idiopathic hypercalciuria are managed with thiazides to reduce calcium excretion and bisphosphonates to inhibit bone resorption when osteoporosis is present. Bisphosphonates also reduce urinary calcium excretion in normal and hypercalciuric patients (186, 187). Thiazides act by stimulating calcium reabsorption in the distal convoluted tubule and also stimulate osteoblast differentiation with a reduction in stone recurrence rate, osteoporotic fractures and an increase in $\operatorname{BMD}(186,188$, $189,190,191,192,193,194,195)$.

Renal tubular acidosis $\bullet$ Renal tubular acidosis (RTA) is a metabolic acidosis caused by either a reduced capacity of the proximal tubule of the kidney to reabsorb the filtered bicarbonate load (proximal) or a reduced capacity of the distal renal tubule to acidify the urine maximally (196). When the hydrogen ion load is greater than the normal daily acid load, bone buffers the hydrogen ions. This may result in a spectrum of metabolic bone disorders ranging from osteomalacia (with proximal RTA) to osteoporosis (with distal RTA) and fractures. Defective renal acidification may lead to an osteoblast-mediated activation of osteoclasts and a compensatory mobilization of alkali and calcium from bone resulting in bone loss $(197,198)$. Calcium reabsorption in the cortical collecting tubule is also reduced in RTA resulting in a negative renal calcium balance. Electrolyte abnormalities including increased chloride $(>110 \mathrm{mEq} / \mathrm{l})$ and low bicarbonate $(<18 \mathrm{mEq} / \mathrm{l})$ raise suspicion for RTA, and patients should be evaluated with arterial blood gases and a determination of urinary $\mathrm{pH}$.

RANKL, TNF $\alpha$ and prostaglandins have been implicated in acid-induced, cell-mediated net calcium efflux from bone $(196,199)$. Simultaneous inhibition of RANKL and TNF $\alpha$ reduce the acid-induced, cell-mediated net calcium efflux from bone in in vitro studies. There are no studies evaluating the role of antiresorptive therapy in RTA.

Chronic kidney disease $>$ The etiology of osteoporosis and fractures in chronic kidney disease (CKD) is multifactorial. The diagnosis of osteoporosis can be made in stages 1-3 CKD only on the basis of a low BMD or a fragility fracture, in the absence of concomitant metabolic abnormalities that suggest the presence of CKD-mineral and bone disorders (200). The metabolic bone disorder encompasses systemic derangements in bone mineralization and turnover associated with systemic vascular calcifications. CKD patients are more likely to fracture because they are at an increased risk for falls from muscle weakness and impaired balance secondary to poor nutrition, inactivity, myopathy and peripheral neuropathy (201). A detailed discussion of renal osteodystrophy is beyond the scope of this review, and reviews of this disorder have recently been published (202).

\section{Autoimmune disorders and osteoporosis}

Rheumatoid arthritis $~$ RA is a chronic inflammatory disease associated with marginal joint erosions, periarticular osteopenia and systemic osteoporosis. Patients with RA have a two- to threefold increased risk of hip and vertebral fractures $(203,204)$. Underlying disease activity and ongoing use of glucocorticoids can contribute to bone loss and risk for fractures. Several cytokines involved in RA-associated inflammation such as IL1, IL6 and TNF $\alpha$ can promote osteoclastic activity. Increased RANKL/OPG ratio, elevated bone turnover markers and sedimentation rate are predicators of rapid and persistent bone loss and articular erosions in patients with RA (205).

Anti-TNF antibodies, used in the treatment of the inflammatory process in RA decrease the systemic bone loss (206). Increased levels of Wnt antagonists, DKK-1 and sclerostin also contribute to the decreased bone formation leading to bone loss; IL6 inhibitors reverse these changes $(207,208)$.

Bisphosphonates are used in the treatment of osteoporosis associated with RA. In a meta-analysis evaluating the use of bisphosphonates on BMD and prevention of vertebral and non-vertebral fractures, a significant reduction in incident vertebral fractures was observed after 18 months of bisphosphonates when used for prevention and after 36 months when used for treatment with preservation of BMD (209).

Systemic lupus erythematosus $>$ Low BMD occurs in up to $50 \%$ of female patients with SLE in the premenopausal age. Race, glucocorticoid intake and cumulative corticosteroid exposure and use of anticoagulants such as heparin are predictors of reduced BMD and osteoporosis $(210,211)$. Other factors such as immunosuppressive drugs, limited physical activity and vitamin D deficiency contribute to the reduced bone mass. A $10-12 \%$ increased risk of fractures is reported in SLE patients. Osteoclast-inducing inflammatory cytokines such as IL6, soluble IL6 receptor, IL1 and TNF $\alpha$ are elevated in SLE and contribute to the bone loss. There is higher incidence of vitamin D 
deficiency in patients with SLE, possibly because patients avoid sun exposure (212). Supplemental calcium and vitamin $\mathrm{D}$ intake should be encouraged. No specific guidelines exist to evaluate the risk of fracture. Management of GIO is discussed under endocrine causes of osteoporosis and bisphosphonates need to be used with caution in women of child bearing age.

Ankylosing spondylitis • Ankylosing spondylitis (AS) is a relatively common cause of chronic arthritis that predominantly affects men. Osteoporosis is seen in up to $25 \%$, and osteopenia in up to $50 \%$, of patients with AS with a higher incidence of both vertebral and nonvertebral fractures (213). The etiology of osteoporosis in patients with AS is multifactorial with systemic inflammation mediated by $\mathrm{TNF} \alpha$ being the most important etiologic factor. Both RANKL induction possibly by TNF $\alpha$ and decrease in Wnt signaling have been implicated in the osteoclast-mediated bone resorption and the dysregulated bone formation in AS; TNF $\alpha$ inhibitors increase vertebral and hip BMD in this condition (214).

Multiple sclerosis $>$ Multiple sclerosis is a chronic demyelinating neurologic condition frequently associated with significant disability and limitation of physical function. Osteoporosis occurs frequently in male and female patients with multiple sclerosis (215). Factors contributing to the low BMD in this population include vitamin D deficiency, glucocorticoid therapy and female gender. Degree of functional impairment, advanced age and duration of disease also contribute significantly to the low BMD found in these patients (216).

Studies comparing BMD between ambulatory patients with multiple sclerosis and healthy control subjects do not show significant differences in BMD (217). However, the level of disability in patients with multiple sclerosis, as measured by the Expanded Disability Status Score, correlates strongly with BMD at the lumbar spine and femoral neck (218).

\section{Drug-induced osteoporosis}

Drug-induced osteoporosis is common and can be caused by a variety of pharmacological agents, including those used for the treatment of endocrine, central nervous system (CNS), immune, cardiovascular and gastrointestinal disorders (Table 2).

Hormones and agents with actions on the endocrine system • Glucocorticoids, thyroid management therapy, and agents that induce hypogonadism and thiazolidinediones are discussed under the section 'Endocrine causes of osteoporosis'.

Drugs with actions on the CNS $~$ Drugs with direct effects on the CNS may have deleterious effects on the skeleton and include antidepressants and anticonvulsants.

Antidepressants $\downarrow$ The use of selective serotonin and norepinephrine reuptake inhibitors (SSRI/SNRI) for the treatment of depression can be associated with bone loss and an increase in the risk of fractures in individuals $\geq 50$ years of age $(219,220)$. The mechanism remains controversial although subjects on SSRI and SNRI exhibit increased biochemical markers of bone remodeling (221). There are no specific guidelines for the prevention of the bone loss associated with SSRI/SNRIs, but screening for osteoporosis should be considered.

Anticonvulsants $>$ Patients with epilepsy are at an increased risk of fractures, and epilepsy itself or its treatment may influence the pathogenesis of fractures (222). Prospective studies have demonstrated a greater decrease in BMD in women $\geq 65$ years of age on anticonvulsants, but many confounders exist in these studies and fractures also are associated with seizure activity $(223,224)$. Anticonvulsants may cause bone loss, but mechanisms responsible are not clear. There is accelerated vitamin D metabolism with certain anticonvulsants and this could lead to low 25-hydroxyvitamin $\mathrm{D}_{3}$ levels, high bone turnover and secondary hyperparathyroidism increasing the risk of fractures $(225,226)$. These changes correlate with the type of anticonvulsant and duration of the treatment. Moreover, there is limited understanding of the pathogenesis of this skeletal disorder so that diagnostic and therapeutic guidelines are not established. Antiepileptic agents known to induce the liver enzymes cytochrome P450 (CYP450) and uridine 5'-diphospho-glucuronosyltransferase include phenytoin, carbamazepine and phenobarbital, and at high doses topiramate (227). Use of these agents is associated with greater risk of fractures than use of non-enzyme inducing antiepileptic drugs (228). The mechanism involves hydroxylation of specific residues leading to the inactivation of 1,25-dihydroxyvitamin $D_{3}$ (229). Similarly, polytherapy is associated with increased risk of fractures. A recent meta-analysis revealed a weak and non-significant association between the use of carbamazepine, valproic acid and gabapentine and fracture risk, and an increase risk of fractures with liver enzyme inducing drugs; namely, phenobarbiturate, topiramate and phenoytoin, of $40-80 \%$ (228). There has 
been an evolution in the management of seizure disorders and much of the evidence linking anticonvulsants to osteoporosis may not apply to newly developed drugs. Calcium, vitamin D supplementation and bisphosphonates were shown to have a beneficial effect on BMD in a small cohort of patients with epilepsy treated with anticonvulsants (230).

Anticholinergic drugs are frequently used in an elderly population for the treatment of a variety of conditions. In a large, population-based cohort of Canadians older than 50 years old, it was found that the use of anticholinergic medications appeared to be associated with an increased risk of falling and non-traumatic fractures in unadjusted analyses; however, after adjusting for confounding variables, there was not a significant association (231). Similarly, an accelerated decline in femoral neck BMD was seen in anticholinergic medication users, but this decline was accounted for by factors other than anticholinergic drug use and after covariate adjustment, no significant association was seen (231).

Drugs with actions on the immune system $>$ Calcineurin inhibitors Calcineurin inhibitors are immunosuppressants used in combination with glucocorticoids in patients undergoing organ transplantation and are associated with an increase in fracture risk (232). Calcineurin inhibitors decrease osteoclastogenesis and bone resorption in vitro (233). However, mouse models harboring either the activation or downregulation of calcineurin have generated conflicting results $(234,235)$. Calcineurin is a phosphatase that dephosphorylates nuclear factors of activated T-cells (NFATs). Nfatc1 is critical for osteoclast formation, and studies from our laboratory have revealed a direct inhibitory effect of Nfatc1 and Nfatc2 on osteoblastogenesis $(236,237,238)$. Accordingly, the conditional inactivation of calcineurin in osteoblasts causes an increase in bone formation and a decrease in bone resorption (235). These observations do not explain the bone loss observed in humans treated with calcineurin inhibitors suggesting that the calcineurin/NFAT axis may not be responsible for the bone disease observed. Alternate targets of calcineurin or the concomitantly administered glucocorticoids may be responsible for the negative impact on skeletal homeostasis. Moreover, patients undergoing liver transplantation may present with osteoporosis, osteopenia or even vertebral fractures prior to transplantation (239). These observations would incriminate the underlying disease as the cause of the bone loss and fractures. Importantly, there is no association between BMD and fractures, highlighting the fact that post-menopausal osteoporosis diagnostic criteria are often not applicable to secondary osteoporosis. Since bone loss occurs prior to, or in the initial months of, immunosuppressive therapy, treatment should be instituted early. Calcium and vitamin D supplementation, and antiresorptive agents should be considered for the prevention of bone loss after transplantation (240).

Antiretrovial therapy Antiretroviral agents are used to treat patients affected by infections with HIV. Crosssectional studies have shown a three- to sevenfold increase in the risk of osteoporosis in patients with HIV infection and an increased risk of fractures in men and women with HIV infection (241). Patients with HIV infection, secondary to illicit drug use may be more exposed to trauma and consequent fractures than the general population. In addition, hepatitis $\mathrm{C}$ infection is a co-morbidity and may contribute to the risk of fractures in patients with HIV infections (149). A recent meta-analysis revealed that patients with HIV infection had a 1.35 incidence rate ratio of fragility fractures compared to controls (242). Predictors of fractures included older age, white race, low BMI, diabetes, liver disease, alcohol, tobacco and substance abuse. Chronic inflammatory conditions found in patients with HIV infection may be associated with increased RANKL expression and enhanced bone turnover. Antiretroviral agents also may cause bone loss although the mechanisms may vary (243). Tenofovir may alter renal function and cause secondary hyperparathyroidism with increased bone resorption. Non-nuclease RT inhibitors are associated with decreased serum levels of vitamin D and protease inhibitors may impair Wnt signaling and decrease osteoblastogenesis (241). Patients with HIV infection treated with tenofovir and certain protease inhibitors suffer greater losses of BMD but the relevance to fracture risk has not been determined. Guidelines for the management of antiretroviral therapy-induced bone loss are available from the European Aids Clinical Society.

Anticoagulants $>$ Heparin is effective in the prevention and treatment of thromboembolic disorders. In vitro, heparin inhibits the differentiation and function of osteoblasts, and in vivo it decreases bone formation and increases bone resorption $(244,245)$. Heparin binds to OPG, the decoy receptor for RANKL, allowing RANKL to induce osteoclastogenesis $(245,246)$. About one-third of patients receiving long-term therapy with heparin display a decrease in BMD, but fractures seldom occur and are less frequent in patients on low-weight heparin than on unfractioned heparin $(247,248,249)$. 
Oral anticoagulants are often used to prevent or treat thromboembolic phenomena, and their effects on bone metabolism are controversial. Anticoagulants with vitamin K antagonist activity, such as warfarin, interfere with $\gamma$-carboxyglutamate formation, and consequently inhibit the accumulation of osteocalcin in the extracellular bone matrix (250). Although these are potentially negative effects, evidence that warfarin causes osteoporosis and fractures is insufficient $(251,252)$.

Diuretics $>$ Loop diuretics are used in the management of congestive heart failure, which itself is associated with an increased risk of fragility fractures (253). Loop diuretics inhibit sodium and chloride reabsorption and inhibit calcium reabsorption, increasing its renal excretion (254). This results in increased bone turnover, decreased BMD and increased risk of osteoporotic fractures $(255,256)$. In contrast, thiazide diuretics cause calcium retention and an increase in serum calcium, and have modest or no effects on BMD or risk of fractures (257).

Drugs with actions on the gastrointestinal tract Proton pump inhibitors $>$ Proton pump inhibitors are commonly used in the management of disorders of the upper gastrointestinal tract. By increasing gastric $\mathrm{pH}$, they may decrease calcium absorption and have negative effects on skeletal homeostasis. However, their impact on BMD or fragility fractures is controversial (258). A large prospective population based Canadian Multicenter Osteoporosis Study and the Women's Health Initiative Observational Study reported a modest association between long-term proton pump inhibitor use and risk of fragility fractures $(259,260$, 261). Although the effect of proton pump inhibitors on fracture risk is modest, it is reasonable to treat these patients with supplemental calcium and vitamin D. A calcium supplement that can be absorbed in the presence of proton pump inhibitors should be considered.

\section{Summary and recommendations}

Patients with osteoporosis frequently have underlying causes for the disease and should be evaluated for their presence. A modification of factors contributing to the bone loss may reverse the bone loss and fracture risk. It is common to find suboptimal calcium and vitamin D intake in these patients, deficiencies that are easily correctable. Basic laboratory evaluation should be considered in all patients, and further testing can be done based on clues from history and initial evaluation to look for causes of bone loss (see Table 3). However, it is important to
Table 3 Evaluation of secondary causes of osteoporosis.

Initial workup

Detailed history to identify risk factors for osteoporosis

Evaluation of nutritional status, calcium and vitamin D intake Bone mineral density

X-ray lumbar and thoracic spine (if height loss $>1.5^{\prime \prime}$ )

Complete blood count with differential

Serum calcium, phosphate, creatinine, albumin and

25-hydroxyvitamin D

Serum protein electrophoresis

Serum total and free testosterone, FSH, $\mathrm{LH}$ and prolactin

Bone resorption and formation markers

$24 \mathrm{~h}$ urine calcium, creatinine and sodium

Further workup

Serum parathyroid hormone

Serum thyroid-stimulating hormone

Serum tissue transglutaminase antibodies

Serum ferritin and liver function tests

Serum electrolytes

Serum tryptase levels

$24 \mathrm{~h}$ urinary cortisol or dexamethasone suppression test Nuclear bone scan (if bone turnover unexplained high)

consider that the prevalence of secondary osteoporosis in patients with fractures is relatively low, particularly among post-menopausal women, and the laboratory costs may be substantial (262). When a drug is responsible for the bone loss, an effort should be made to use the lowest dose of the medication, as in the case of glucocorticoids so that the risk of bone loss and fracture risk is minimized.

The validity of BMD as a predictor of fractures has not been established in patients with secondary causes of osteoporosis. Fractures may occur at reasonably normal BMDs limiting the value of BMD in these patients. Treatment interventions may vary depending on the cause of bone loss since the underlying cause may influence the response to therapy. Whereas therapies directed to the treatment of osteoporosis may be effective, treating the underlying disease is essential for a successful outcome.

Declaration of interest

The authors declare that there is no conflict of interest that could be perceived as prejudicing the impartiality of the review.

\section{Funding}

This work was in part supported by grants AR063049 (E Canalis) and DK045227 (E Canalis) from the National Institutes of Health.

\section{Acknowledgements}

The authors thank Mary Yurczak for secretarial assistance. 


\section{References}

1 Painter SE, Kleerekoper M \& Camacho PM. Secondary osteoporosis: a review of the recent evidence. Endocrine Practice 200612 436-445. (doi:10.4158/EP.12.4.436)

2 Harper KD \& Weber TJ. Secondary osteoporosis. Diagnostic considerations. Endocrinology and Metabolism Clinics of North America 199827 325-348. (doi:10.1016/S0889-8529(05)70008-6)

3 NIH Consensus Development Panel on Osteoporosis Prevention, Diagnosis, and Therapy. Osteoporosis prevention, diagnosis, and therapy. Journal of the American Medical Association 2001285 785-795. (doi:10.1001/jama.285.6.785)

4 Panico A, Lupoli GA, Fonderico F, Marciello F, Martinelli A, Assante R $\&$ Lupoli G. Osteoporosis and thyrotropin-suppressive therapy: reduced effectiveness of alendronate. Thyroid 200919 437-442. (doi:10.1089/thy.2008.0428)

5 Giusti A, Barone A, Pioli G, Girasole G, Siccardi V, Palummeri E \& Bianchi G. Alendronate and indapamide alone or in combination in the management of hypercalciuria associated with osteoporosis: a randomized controlled trial of two drugs and three treatments. Nephrology, Dialysis, Transplantation 200924 1472-1477. (doi:10.1093/ ndt/gfn690)

6 Lindahl K, Langdahl B, Ljunggren O \& Kindmark A. Treatment of osteogenesis imperfecta in adults. European Journal of Endocrinology 2014171 R79-R90. (doi:10.1530/EJE-14-0017)

7 Barbour KE, Lui LY, Ensrud KE, Hillier TA, LeBlanc ES, Ing SW, Hochberg MC, Cauley JA \& Study of Osteoporotic Fractures Research G. Inflammatory markers and risk of hip fracture in older white women: the study of osteoporotic fractures. Journal of Bone and Mineral Research 201429 2057-2064. (doi:10.1002/jbmr.2245)

8 Kanis JA, Johansson H, Oden A \& McCloskey EV. Guidance for the adjustment of FRAX according to the dose of glucocorticoids. Osteoporosis International 201122 809-816. (doi:10.1007/s00198-010-1524-7)

9 van Staa TP, Leufkens HG \& Cooper C. The epidemiology of corticosteroid-induced osteoporosis: a meta-analysis. Osteoporosis International 200213 777-787. (doi:10.1007/s001980200108)

10 van Staa TP, Leufkens HG, Abenhaim L, Zhang B \& Cooper C. Use of oral corticosteroids and risk of fractures. Journal of Bone and Mineral Research 200015 993-1000. (doi:10.1359/jbmr.2000.15.6.993)

11 Saag KG, Emkey R, Schnitzer TJ, Brown JP, Hawkins F, Goemaere S, Thamsborg G, Liberman UA, Delmas PD, Malice MP et al. Alendronate for the prevention and treatment of glucocorticoid-induced osteoporosis. Glucocorticoid-Induced Osteoporosis Intervention Study Group. New England Journal of Medicine 1998339 292-299. (doi:10.1056/NEJM199807303390502)

12 De Vries F, Bracke M, Leufkens HG, Lammers JW, Cooper C \& Van Staa TP. Fracture risk with intermittent high-dose oral glucocorticoid therapy. Arthritis and Rheumatism 200756 208-214. (doi:10.1002/art.22294)

13 Israel E, Banerjee TR, Fitzmaurice GM, Kotlov TV, LaHive K \& LeBoff MS. Effects of inhaled glucocorticoids on bone density in premenopausal women. New England Journal of Medicine 2001345 941-947. (doi:10.1056/NEJMoa002304)

14 Canalis E, Mazziotti G, Giustina A \& Bilezikian JP. Glucocorticoidinduced osteoporosis: pathophysiology and therapy. Osteoporosis International 200718 1319-1328. (doi:10.1007/s00198-007-0394-0)

15 Hofbauer LC, Gori F, Riggs BL, Lacey DL, Dunstan CR, Spelsberg TC \& Khosla S. Stimulation of osteoprotegerin ligand and inhibition of osteoprotegerin production by glucocorticoids in human osteoblastic lineage cells: potential paracrine mechanisms of glucocorticoidinduced osteoporosis. Endocrinology 1999140 4382-4389. (doi:10.1210/endo.140.10.7034)

16 Kim HJ, Zhao H, Kitaura H, Bhattacharyya S, Brewer JA, Muglia LJ, Ross FP \& Teitelbaum SL. Glucocorticoids suppress bone formation via the osteoclast. Journal of Clinical Investigation 2006116 2152-2160. (doi:10.1172/JCI28084)
17 Pereira RC, Delany AM \& Canalis E. Effects of cortisol and bone morphogenetic protein-2 on stromal cell differentiation: correlation with CCAAT-enhancer binding protein expression. Bone 200230 685-691. (doi:10.1016/S8756-3282(02)00687-7)

18 Canalis E. Wnt signalling in osteoporosis: mechanisms and novel therapeutic approaches. Nature Reviews. Endocrinology 2013 9 575-583. (doi:10.1038/nrendo.2013.154)

19 Smith E \& Frenkel B. Glucocorticoids inhibit the transcriptional activity of LEF/TCF in differentiating osteoblasts in a glycogen synthase kinase-33-dependent and -independent manner. Journal of Biological Chemistry 2005280 2388-2394. (doi:10.1074/jbc.M406294200)

20 Delany AM, Durant D \& Canalis E. Glucocorticoid suppression of IGFI transcription in osteoblasts. Molecular Endocrinology 200115 1781-1789. (doi:10.1210/mend.15.10.0704)

21 Giustina A, Mazziotti G \& Canalis E. Growth hormone, insulin-like growth factors, and the skeleton. Endocrine Reviews 200829 535-559. (doi:10.1210/er.2007-0036)

22 Dallas SL, Prideaux M \& Bonewald LF. The osteocyte: an endocrine cell ... and more. Endocrine Reviews 201334 658-690. (doi:10.1210/ er.2012-1026)

23 Giustina A \& Veldhuis JD. Pathophysiology of the neuroregulation of growth hormone secretion in experimental animals and the human. Endocrine Reviews 199819 717-797. (doi:10.1210/edrv.19.6.0353)

24 Canalis E. Clinical review 83: Mechanisms of glucocorticoid action in bone: implications to glucocorticoid-induced osteoporosis. Journal of Clinical Endocrinology and Metabolism 199681 3441-3447. (doi:10.1210/jcem.81.10.8855781)

25 Diederich S, Quinkler M, Burkhardt P, Grossmann C, Bahr V \& Oelkers W. 11Beta-hydroxysteroid-dehydrogenase isoforms: tissue distribution and implications for clinical medicine. European Journal of Clinical Investigation 200030 (Suppl 3) 21-27. (doi:10.1046/j.13652362.2000.0300s3021.x)

26 Tannin GM, Agarwal AK, Monder C, New MI \& White PC. The human gene for 11ß-hydroxysteroid dehydrogenase. Structure, tissue distribution, and chromosomal localization. Journal of Biological Chemistry $199126616653-16658$.

27 Cooper MS, Rabbitt EH, Goddard PE, Bartlett WA, Hewison M \& Stewart PM. Osteoblastic 11 $\beta$-hydroxysteroid dehydrogenase type 1 activity increases with age and glucocorticoid exposure. Journal of Bone and Mineral Research 200217 979-986. (doi:10.1359/jbmr.2002.17.6.979)

28 Cooper MS, Walker EA, Bland R, Fraser WD, Hewison M \& Stewart PM. Expression and functional consequences of 11ß-hydroxysteroid dehydrogenase activity in human bone. Bone 200027 375-381. (doi:10.1016/S8756-3282(00)00344-6)

29 Canalis E. Mechanisms of glucocorticoid-induced osteoporosis. Current Opinion in Rheumatology 200315 454-457. (doi:10.1097/ 00002281-200307000-00013)

30 Angeli A, Guglielmi G, Dovio A, Capelli G, de Feo D, Giannini S, Giorgino R, Moro L \& Giustina A. High prevalence of asymptomatic vertebral fractures in post-menopausal women receiving chronic glucocorticoid therapy: a cross-sectional outpatient study. Bone 2006 39 253-259. (doi:10.1016/j.bone.2006.02.005)

31 Grossman JM, Gordon R, Ranganath VK, Deal C, Caplan L, Chen W, Curtis JR, Furst DE, McMahon M, Patkar NM et al. American College of Rheumatology 2010 recommendations for the prevention and treatment of glucocorticoid-induced osteoporosis. Arthritis Care \& Research 201062 1515-1526. (doi:10.1002/acr.20295)

32 van Staa TP, Laan RF, Barton IP, Cohen S, Reid DM \& Cooper C. Bone density threshold and other predictors of vertebral fracture in patients receiving oral glucocorticoid therapy. Arthritis and Rheumatism 2003 48 3224-3229. (doi:10.1002/art.11283)

33 Lekamwasam S, Adachi JD, Agnusdei D, Bilezikian J, Boonen S, Borgstrom F, Cooper C, Diez Perez A, Eastell R, Hofbauer LC et al. A framework for the development of guidelines for the management of glucocorticoid-induced osteoporosis. Osteoporosis International 2012 23 2257-2276. (doi:10.1007/s00198-012-1958-1) 
34 Dovio A, Perazzolo L, Osella G, Ventura M, Termine A, Milano E, Bertolotto A \& Angeli A. Immediate fall of bone formation and transient increase of bone resorption in the course of high-dose, shortterm glucocorticoid therapy in young patients with multiple sclerosis. Journal of Clinical Endocrinology and Metabolism 200489 4923-4928. (doi:10.1210/jc.2004-0164)

35 Szappanos A, Toke J, Lippai D, Patocs A, Igaz P, Szucs N, Futo L, Glaz E, Racz K \& Toth M. Bone turnover in patients with endogenous Cushing's syndrome before and after successful treatment. Osteoporosis International 201021 637-645. (doi:10.1007/s00198-009-0978-y)

36 Buckley LM, Leib ES, Cartularo KS, Vacek PM \& Cooper SM. Calcium and vitamin D3 supplementation prevents bone loss in the spine secondary to low-dose corticosteroids in patients with rheumatoid arthritis. A randomized, double-blind, placebo-controlled trial. Annals of Internal Medicine 1996125 961-968. (doi:10.7326/0003-4819-12512-199612150-00004)

37 Godschalk M, Levy JR \& Downs RW Jr. Glucocorticoids decrease vitamin $\mathrm{D}$ receptor number and gene expression in human osteosarcoma cells. Journal of Bone and Mineral Research 19927 21-27. (doi:10.1002/jbmr.5650070105)

38 Hidalgo AA, Deeb KK, Pike JW, Johnson CS \& Trump DL. Dexamethasone enhances $1 \alpha, 25$-dihydroxyvitamin D3 effects by increasing vitamin D receptor transcription. Journal of Biological Chemistry 2011286 36228-36237. (doi:10.1074/jbc.M111.244061)

39 Adachi JD, Bensen WG, Bianchi F, Cividino A, Pillersdorf S, Sebaldt RJ, Tugwell P, Gordon M, Steele M, Webber C et al. Vitamin D and calcium in the prevention of corticosteroid induced osteoporosis: a 3 year followup. Journal of Rheumatology 199623 995-1000.

40 Reid DM, Devogelaer JP, Saag K, Roux C, Lau CS, Reginster JY, Papanastasiou P, Ferreira A, Hartl F, Fashola T et al. Zoledronic acid and risedronate in the prevention and treatment of glucocorticoidinduced osteoporosis (HORIZON): a multicentre, double-blind, double-dummy, randomised controlled trial. Lancet $20093 \mathbf{3 7 3}$ 1253-1263. (doi:10.1016/S0140-6736(09)60250-6)

41 Thomas T, Horlait S, Ringe JD, Abelson A, Gold DT, Atlan P \& Lange JL. Oral bisphosphonates reduce the risk of clinical fractures in glucocorticoid-induced osteoporosis in clinical practice. Osteoporosis International 201324 263-269. (doi:10.1007/s00198-012-2060-4)

42 Saag KG, Shane E, Boonen S, Marin F, Donley DW, Taylor KA, Dalsky GP \& Marcus R. Teriparatide or alendronate in glucocorticoidinduced osteoporosis. New England Journal of Medicine 2007357 2028-2039. (doi:10.1056/NEJMoa071408)

43 Bassett JH \& Williams GR. Critical role of the hypothalamic-pituitarythyroid axis in bone. Bone 200843 418-426. (doi:10.1016/j.bone. 2008.05.007)

44 Bassett JH \& Williams GR. The molecular actions of thyroid hormone in bone. Trends in Endocrinology and Metabolism 200314 356-364. (doi:10.1016/S1043-2760(03)00144-9)

45 Bauer DC, Ettinger B, Nevitt MC, Stone KL \& Study of Osteoporotic Fractures Research G. Risk for fracture in women with low serum levels of thyroid-stimulating hormone. Annals of Internal Medicine 2001134 561-568. (doi:10.7326/0003-4819-134-7-200104030-00009)

46 Abrahamsen B, Jorgensen HL, Laulund AS, Nybo M, Brix TH \& Hegedus L. Low serum thyrotropin level and duration of suppression as a predictor of major osteoporotic fractures - the OPENTHYRO register cohort. Journal of Bone and Mineral Research 201429 2040-2050. (doi:10.1002/jbmr.2244)

47 Cummings SR, Nevitt MC, Browner WS, Stone K, Fox KM, Ensrud KE, Cauley J, Black D \& Vogt TM. Risk factors for hip fracture in white women. Study of Osteoporotic Fractures Research Group. New England Journal of Medicine 1995332 767-773. (doi:10.1056/NEJM199503233321202)

48 Vestergaard P \& Mosekilde L. Fractures in patients with hyperthyroidism and hypothyroidism: a nationwide follow-up study in 16,249 patients. Thyroid 200212 411-419. (doi:10.1089/105072502760043503)

49 Abe E, Marians RC, Yu W, Wu XB, Ando T, Li Y, Iqbal J, Eldeiry L, Rajendren G, Blair HC et al. TSH is a negative regulator of skeletal remodeling. Cell 2003115 151-162. (doi:10.1016/S00928674(03)00771-2)

50 van Rijn LE, Pop VJ \& Williams GR. Low bone mineral density is related to high physiological levels of free thyroxine in perimenopausal women. European Journal of Endocrinology 2014170 461-468. (doi:10.1530/EJE-13-0769)

51 Biondi B \& Wartofsky L. Treatment with thyroid hormone. Endocrine Reviews 201435 433-512. (doi:10.1210/er.2013-1083)

52 Heemstra KA, Hamdy NA, Romijn JA \& Smit JW. The effects of thyrotropin-suppressive therapy on bone metabolism in patients with well-differentiated thyroid carcinoma. Thyroid 200616 583-591. (doi:10.1089/thy.2006.16.583)

53 Sheppard MC, Holder R \& Franklyn JA. Levothyroxine treatment and occurrence of fracture of the hip. Archives of Internal Medicine 2002162 338-343. (doi:10.1001/archinte.162.3.338)

54 Tuck SP \& Francis RM. Testosterone, bone and osteoporosis. Frontiers of Hormone Research 200937 123-132. (doi:10.1159/000176049)

55 Krupski TL, Smith MR, Lee WC, Pashos CL, Brandman J, Wang Q, Botteman M \& Litwin MS. Natural history of bone complications in men with prostate carcinoma initiating androgen deprivation therapy. Cancer 2004101 541-549. (doi:10.1002/cncr.20388)

56 Malcolm JB, Derweesh IH, Kincade MC, DiBlasio CJ, Lamar KD, Wake RW \& Patterson AL. Osteoporosis and fractures after androgen deprivation initiation for prostate cancer. Canadian Journal of Urology 200714 3551-3559.

57 Leder BZ, LeBlanc KM, Schoenfeld DA, Eastell R \& Finkelstein JS. Differential effects of androgens and estrogens on bone turnover in normal men. Journal of Clinical Endocrinology and Metabolism $2003 \mathbf{8 8}$ 204-210. (doi:10.1210/jc.2002-021036)

58 Hofbauer LC \& Khosla S. Androgen effects on bone metabolism: recent progress and controversies. European Journal of Endocrinology 1999140 271-286. (doi:10.1530/eje.0.1400271)

59 Pederson L, Kremer M, Judd J, Pascoe D, Spelsberg TC, Riggs BL \& Oursler MJ. Androgens regulate bone resorption activity of isolated osteoclasts in vitro. PNAS 199996 505-510. (doi:10.1073/pnas.96.2.505)

60 Kasperk CH, Wakley GK, Hierl T \& Ziegler R. Gonadal and adrenal androgens are potent regulators of human bone cell metabolism in vitro. Journal of Bone and Mineral Research 199712 464-471. (doi:10.1359/jbmr.1997.12.3.464)

61 Huber DM, Bendixen AC, Pathrose P, Srivastava S, Dienger KM, Shevde NK \& Pike JW. Androgens suppress osteoclast formation induced by RANKL and macrophage-colony stimulating factor. Endocrinology 2001 142 3800-3808. (doi:10.1210/endo.142.9.8402)

62 Behre HM, Kliesch S, Leifke E, Link TM \& Nieschlag E. Long-term effect of testosterone therapy on bone mineral density in hypogonadal men. Journal of Clinical Endocrinology and Metabolism 199782 2386-2390. (doi:10.1210/jcem.82.8.4163)

63 Giusti A \& Bianchi G. Treatment of primary osteoporosis in men. Clinical Interventions in Aging 201510 105-115. (doi:10.2147/CIA.S44057)

64 Pepene CE, Crisan N \& Coman I. Elevated serum receptor activator of nuclear factor $\kappa \mathrm{B}$ ligand and osteoprotegerin levels in late-onset male hypogonadism. Clinical and Investigative Medicine. Médecine Clinique et Experimental 201134 E232.

65 Parthan A, Kruse M, Agodoa I, Silverman S \& Orwoll E. Denosumab: a cost-effective alternative for older men with osteoporosis from a Swedish payer perspective. Bone 201459 105-113. (doi:10.1016/ j.bone.2013.11.002)

66 Pavone ME \& Bulun SE. Clinical review: The use of aromatase inhibitors for ovulation induction and superovulation. Journal of Clinical Endocrinology and Metabolism 201398 1838-1844. (doi:10.1210/jc.2013-1328)

67 Legro RS, Brzyski RG, Diamond MP, Coutifaris C, Schlaff WD, Casson P, Christman GM, Huang H, Yan Q, Alvero R et al. Letrozole versus clomiphene for infertility in the polycystic ovary syndrome. New England Journal of Medicine 2014371 119-129. (doi:10.1056/ NEJMoa1313517) 
68 Coleman RE, Banks LM, Girgis SI, Kilburn LS, Vrdoljak E, Fox J, Cawthorn SJ, Patel A, Snowdon CF, Hall E et al. Skeletal effects of exemestane on bone-mineral density, bone biomarkers, and fracture incidence in postmenopausal women with early breast cancer participating in the Intergroup Exemestane Study (IES): a randomised controlled study. Lancet Oncology 20078 119-127. (doi:10.1016/ S1470-2045(07)70003-7)

69 Eastell R, Hannon RA, Cuzick J, Dowsett M, Clack G, Adams JE \& ATAC Trialists' group. Effect of an aromatase inhibitor on BMD and bone turnover markers: 2-year results of the Anastrozole, Tamoxifen, Alone or in Combination (ATAC) trial (18233230). Journal of Bone and Mineral Research 200621 1215-1223. (doi:10.1359/jbmr.060508)

70 Howell A, Cuzick J, Baum M, Buzdar A, Dowsett M, Forbes JF, HoctinBoes G, Houghton J, Locker GY, Tobias JS et al. Results of the ATAC (Arimidex, Tamoxifen, Alone or in Combination) trial after completion of 5 years' adjuvant treatment for breast cancer. Lancet 2005 365 60-62. (doi:10.1016/S0140-6736(05)74803-0)

71 Kaunitz AM, Arias R \& McClung M. Bone density recovery after depot medroxyprogesterone acetate injectable contraception use. Contraception 200877 67-76. (doi:10.1016/j.contraception.2007.10.005)

72 Cann CE. Bone densitometry as an adjunct to GnRH agonist therapy. Journal of Reproductive Medicine 199843 321-330.

73 Pierce SJ, Gazvani MR \& Farquharson RG. Long-term use of gonadotropin-releasing hormone analogs and hormone replacement therapy in the management of endometriosis: a randomized trial with a 6-year follow-up. Fertility and Sterility 200074 964-968. (doi:10.1016/ S0015-0282(00)01537-5)

74 Greenspan SL, Coates P, Sereika SM, Nelson JB, Trump DL \& Resnick NM. Bone loss after initiation of androgen deprivation therapy in patients with prostate cancer. Journal of Clinical Endocrinology and Metabolism 200590 6410-6417. (doi:10.1210/jc.2005-0183)

75 Lopez AM, Pena MA, Hernandez R, Val F, Martin B \& Riancho JA. Fracture risk in patients with prostate cancer on androgen deprivation therapy. Osteoporosis International 200516 707-711. (doi:10.1007/ s00198-004-1799-7)

76 Shahinian VB, Kuo YF, Freeman JL \& Goodwin JS. Risk of fracture after androgen deprivation for prostate cancer. New England Journal of Medicine 2005352 154-164. (doi:10.1056/NEJMoa041943)

77 Smith MR, Lee WC, Brandman J, Wang Q, Botteman M \& Pashos CL. Gonadotropin-releasing hormone agonists and fracture risk: a claimsbased cohort study of men with nonmetastatic prostate cancer. Journal of Clinical Oncology 200523 7897-7903. (doi:10.1200/JCO.2004.00.6908)

78 Townsend MF, Sanders WH, Northway RO \& Graham SD Jr. Bone fractures associated with luteinizing hormone-releasing hormone agonists used in the treatment of prostate carcinoma. Cancer $1997 \mathbf{7 9}$ 545-550. (doi:10.1002/(SICI)1097-0142(19970201)79:3<545::AIDCNCR17> 3.0.CO;2-3)

79 Hamilton EJ, Ghasem-Zadeh A, Gianatti E, Lim-Joon D, Bolton D, Zebaze R, Seeman E, Zajac JD \& Grossmann M. Structural decay of bone microarchitecture in men with prostate cancer treated with androgen deprivation therapy. Journal of Clinical Endocrinology and Metabolism 201095 E456-E463. (doi:10.1210/jc.2010-0902)

80 Greenspan SL, Nelson JB, Trump DL \& Resnick NM. Effect of onceweekly oral alendronate on bone loss in men receiving androgen deprivation therapy for prostate cancer: a randomized trial. Annals of Internal Medicine 2007146 416-424. (doi:10.7326/0003-4819-146-6200703200-00006)

81 Greenspan SL. Approach to the prostate cancer patient with bone disease. Journal of Clinical Endocrinology and Metabolism 200893 2-7. (doi:10.1210/jc.2007-1402)

82 Kearns AE, Northfelt DW, Dueck AC, Atherton PJ, Dakhil SR, Rowland KM Jr, Fuloria J, Flynn PJ, Dentchev T \& Loprinzi CL. Osteoporosis prevention in prostate cancer patients receiving androgen ablation therapy: placebo-controlled double-blind study of estradiol and risedronate: N01C8. Supportive Care in Cancer 201018 321-328. (doi:10.1007/s00520-009-0655-x)
83 Smith MR, Fallon MA, Lee H \& Finkelstein JS. Raloxifene to prevent gonadotropin-releasing hormone agonist-induced bone loss in men with prostate cancer: a randomized controlled trial. Journal of Clinical Endocrinology and Metabolism 200489 3841-3846. (doi:10.1210/jc. 2003-032058)

84 Smith MR, Malkowicz SB, Chu F, Forrest J, Sieber P, Barnette KG, Rodriquez D \& Steiner MS. Toremifene improves lipid profiles in men receiving androgen-deprivation therapy for prostate cancer: interim analysis of a multicenter phase III study. Journal of Clinical Oncology 200826 1824-1829. (doi:10.1200/JCO.2007.13.5517)

85 Smith MR, Egerdie B, Hernandez Toriz N, Feldman R, Tammela TL, Saad F, Heracek J, Szwedowski M, Ke C, Kupic A et al. Denosumab in men receiving androgen-deprivation therapy for prostate cancer. New England Journal of Medicine 2009361 745-755. (doi:10.1056/ NEJMoa0809003)

86 Bandeira F, Cusano NE, Silva BC, Cassibba S, Almeida CB, Machado VC $\&$ Bilezikian JP. Bone disease in primary hyperparathyroidism. Arquivos Brasileiros de Endocrinologia e Metabologia 201458 553-561. (doi:10.1590/0004-2730000003381)

87 Christiansen P. The skeleton in primary hyperparathyroidism: a review focusing on bone remodeling, structure, mass, and fracture. APMIS. Supplementum 2001 [In press].

88 Khosla S, Melton LJ III, Wermers RA, Crowson CS, O'Fallon W \& Riggs B. Primary hyperparathyroidism and the risk of fracture: a population-based study. Journal of Bone and Mineral Research 199914 1700-1707. (doi:10.1359/jbmr.1999.14.10.1700)

89 Vestergaard P, Mollerup CL, Frokjaer VG, Christiansen P, BlichertToft M \& Mosekilde L. Cohort study of risk of fracture before and after surgery for primary hyperparathyroidism. BMJ 2000321 598-602. (doi:10.1136/bmj.321.7261.598)

90 Khan A, Grey A \& Shoback D. Medical management of asymptomatic primary hyperparathyroidism: proceedings of the Third International Workshop. Journal of Clinical Endocrinology and Metabolism 200994 373-381. (doi:10.1210/jc.2008-1762)

91 Fountas A, Andrikoula M, Giotaki Z, Limniati C, Tsakiridou E, Tigas S $\&$ Tsatsoulis A. The emerging role of denosumab in the long-term management of parathyroid carcinoma-related refractory hypercalcemia. Endocrine Practice 201521 468-473. (doi:10.4158/EP14410.OR)

92 Karuppiah D, Thanabalasingham G, Shine B, Wang LM, Sadler GP, Karavitaki N \& Grossman AB. Refractory hypercalcaemia secondary to parathyroid carcinoma: response to high-dose denosumab. European Journal of Endocrinology 2014171 K1-K5. (doi:10.1530/EJE-14-0166)

93 Nadarasa K, Theodoraki A, Kurzawinski TR, Carpenter R, Bull J, Chung TT \& Drake WM. Denosumab for management of refractory hypercalcaemia in recurrent parathyroid carcinoma. European Journal of Endocrinology 2014171 L7-L8. (doi:10.1530/EJE-14-0482)

94 Tong CV, Hussein Z, Noor NM, Mohamad M \& Ng WF. Use of denosumab in parathyroid carcinoma with refractory hypercalcemia. QJM: Monthly Journal of the Association of Physicians 2015108 49-50. (doi:10.1093/qjmed/hcu166)

95 Camozzi V, Luisetto G, Basso SM, Cappelletti P, Tozzoli R \& Lumachi F. Treatment of chronic hypercalcemia. Medicinal Chemistry 20128 556-563. (doi:10.2174/157340612801216355)

96 Janghorbani M, Feskanich D, Willett WC \& Hu F. Prospective study of diabetes and risk of hip fracture: the Nurses' Health Study. Diabetes Care 200629 1573-1578. (doi:10.2337/dc06-0440)

97 Nicodemus KK, Folsom AR \& Iowa Women's Health S. Type 1 and type 2 diabetes and incident hip fractures in postmenopausal women. Diabetes Care 200124 1192-1197. (doi:10.2337/diacare.24.7.1192)

98 Vestergaard P. Discrepancies in bone mineral density and fracture risk in patients with type 1 and type 2 diabetes - a meta-analysis. Osteoporosis International 200718 427-444. (doi:10.1007/s00198-006-0253-4)

99 Leidig-Bruckner G, Grobholz S, Bruckner T, Scheidt-Nave C, Nawroth P \& Schneider JG. Prevalence and determinants of osteoporosis in patients with type 1 and type 2 diabetes mellitus. BMC Endocrine Disorders 201414 33. (doi:10.1186/1472-6823-14-33) 
100 Leslie WD, Aubry-Rozier B, Lamy O, Hans D \& Manitoba Bone Density P. TBS (trabecular bone score) and diabetes-related fracture risk. Journal of Clinical Endocrinology and Metabolism 201398 602-609. (doi:10.1210/jc.2012-3118)

101 Ali AA, Weinstein RS, Stewart SA, Parfitt AM, Manolagas SC \& Jilka RL. Rosiglitazone causes bone loss in mice by suppressing osteoblast differentiation and bone formation. Endocrinology 2005146 1226-1235. (doi:10.1210/en.2004-0735)

102 Shockley KR, Rosen CJ, Churchill GA \& Lecka-Czernik B. PPAR $\gamma 2$ regulates a molecular signature of marrow mesenchymal stem cells. PPAR Research 20072007 81219. (doi:10.1155/2007/81219)

103 Wan Y, Chong LW \& Evans RM. PPAR- $\gamma$ regulates osteoclastogenesis in mice. Nature Medicine 200713 1496-1503. (doi:10.1038/nm1672)

104 Habib ZA, Havstad SL, Wells K, Divine G, Pladevall M \& Williams LK. Thiazolidinedione use and the longitudinal risk of fractures in patients with type 2 diabetes mellitus. Journal of Clinical Endocrinology and Metabolism 201095 592-600. (doi:10.1210/jc.2009-1385)

105 Schwartz AV, Sellmeyer DE, Vittinghoff E, Palermo L, Lecka-Czernik B, Feingold KR, Strotmeyer ES, Resnick HE, Carbone L, Beamer BA et al. Thiazolidinedione use and bone loss in older diabetic adults. Journal of Clinical Endocrinology and Metabolism 200691 3349-3354. (doi:10.1210/jc.2005-2226)

106 Kuzma M \& Payer J. Growth hormone deficiency, its influence on bone mineral density and risk of osteoporotic fractures. Casopís Lékaru Ceských 2010149 211-216.

107 Aimaretti G, Corneli G, Rovere S, Croce CG, Ghigo E \& Procopio M. Is GH therapy useful to preserve bone mass in transition-phase patients with GH deficiency? Journal of Endocrinological Investigation 200528 28-32.

108 Mazziotti G, Bianchi A, Bonadonna S, Nuzzo M, Cimino V, Fusco A, De Marinis L \& Giustina A. Increased prevalence of radiological spinal deformities in adult patients with GH deficiency: influence of GH replacement therapy. Journal of Bone and Mineral Research 200621 520-528. (doi:10.1359/jbmr.060112)

109 Mazziotti G, Chiavistelli S \& Giustina A. Pituitary diseases and bone. Endocrinology and Metabolism Clinics of North America 201544 171-180. (doi:10.1016/j.ecl.2014.10.014)

110 Mazziotti G, Biagioli E, Maffezzoni F, Spinello M, Serra V, Maroldi R, Floriani I \& Giustina A. Bone turnover, bone mineral density, and fracture risk in acromegaly: a meta-analysis. Journal of Clinical Endocrinology and Metabolism 2015100 384-394. (doi:10.1210/jc.2014-2937)

111 Mazziotti G, Bianchi A, Porcelli T, Mormando M, Maffezzoni F, Cristiano A, Giampietro A, De Marinis L \& Giustina A. Vertebral fractures in patients with acromegaly: a 3-year prospective study. Journal of Clinical Endocrinology and Metabolism 201398 3402-3410. (doi:10.1210/jc.2013-1460)

112 Meyer D, Stavropolous S, Diamond B, Shane E \& Green PH. Osteoporosis in a North American adult population with celiac disease. American Journal of Gastroenterology 200196 112-119. (doi:10.1111/j.1572-0241.2001.03507.x)

113 Guevara Pacheco G, Chavez Cortes E \& Castillo-Duran C. Micronutrient deficiencies and celiac disease in pediatrics. Archivos Argentinos de Pediatría 2014112 457-463. (doi:10.1590/S0325-00752014000500012)

114 Duerksen DR \& Leslie WD. Positive celiac disease serology and reduced bone mineral density in adult women. Canadian Journal of Gastroenterology 201024 103-107.

115 Heikkila K, Pearce J, Maki M \& Kaukinen K. Coeliac disease and bone fractures: a systematic review and meta-analysis. Journal of Clinical Endocrinology and Metabolism 2014100 25-34. (doi:10.1210/jc.2014-1858)

116 Di Stefano M, Mengoli C, Bergonzi M \& Corazza GR. Bone mass and mineral metabolism alterations in adult celiac disease: pathophysiology and clinical approach. Nutrients 20135 4786-4799. (doi:10.3390/ nu5114786)

117 Corazza GR, Di Stefano M, Maurino E \& Bai JC. Bones in coeliac disease: diagnosis and treatment. Best Practice \& Research. Clinical Gastroenterology 200519 453-465. (doi:10.1016/j.bpg.2005.01.002)
118 Bernstein CN, Leslie WD \& Leboff MS. AGA technical review on osteoporosis in gastrointestinal diseases. Gastroenterology $2003 \mathbf{1 2 4}$ 795-841. (doi:10.1053/gast.2003.50106)

119 van Staa TP, Cooper C, Brusse LS, Leufkens H, Javaid MK \& Arden NK. Inflammatory bowel disease and the risk of fracture. Gastroenterology 2003125 1591-1597. (doi:10.1053/j.gastro.2003.09.027)

120 Laakso S, Valta H, Verkasalo M, Toiviainen-Salo S \& Makitie O. Compromised peak bone mass in patients with inflammatory bowel disease - a prospective study. Journal of Pediatrics 2014164 1436-1443.e1. (doi:10.1016/j.jpeds.2014.01.073)

121 Targownik LE, Bernstein CN, Nugent Z, Johansson H, Oden A, McCloskey E, Kanis JA \& Leslie WD. Inflammatory bowel disease and the risk of fracture after controlling for FRAX. Journal of Bone and Mineral Research 201328 1007-1013. (doi:10.1002/jbmr.1848)

122 Mahida YR, Wu K \& Jewell DP. Enhanced production of interleukin $1-\beta$ by mononuclear cells isolated from mucosa with active ulcerative colitis of Crohn's disease. Gut 198930 835-838. (doi:10.1136/gut.30.6.835)

123 Paganelli M, Albanese C, Borrelli O, Civitelli F, Canitano N, Viola F, Passariello R \& Cucchiara S. Inflammation is the main determinant of low bone mineral density in pediatric inflammatory bowel disease. Inflammatory Bowel Diseases 200713 416-423. (doi:10.1002/ibd. 20039)

124 Kumar S, Votta BJ, Rieman DJ, Badger AM, Gowen M \& Lee JC. IL-1- and TNF-induced bone resorption is mediated by p38 mitogen activated protein kinase. Journal of Cellular Physiology 2001187 294-303. (doi:10.1002/jcp.1082)

125 Zhang YH, Heulsmann A, Tondravi MM, Mukherjee A \& Abu-Amer Y. Tumor necrosis factor- $\alpha$ (TNF) stimulates RANKL-induced osteoclastogenesis via coupling of TNF type 1 receptor and RANK signaling pathways. Journal of Biological Chemistry 2001276 563-568. (doi:10.1074/jbc.M008198200)

126 Mauro M, Radovic V \& Armstrong D. Improvement of lumbar bone mass after infliximab therapy in Crohn's disease patients. Canadian Journal of Gastroenterology 200721 637-642.

127 Ezri J, Marques-Vidal P \& Nydegger A. Impact of disease and treatments on growth and puberty of pediatric patients with inflammatory bowel disease. Digestion 201285 308-319. (doi:10.1159/000336766)

128 Gokhale R, Favus MJ, Karrison T, Sutton MM, Rich B \& Kirschner BS. Bone mineral density assessment in children with inflammatory bowel disease. Gastroenterology 1998114 902-911. (doi:10.1016/ S0016-5085(98)70309-9)

129 Lopes LH, Sdepanian VL, Szejnfeld VL, de Morais MB \& FagundesNeto U. Risk factors for low bone mineral density in children and adolescents with inflammatory bowel disease. Digestive Diseases and Sciences 200853 2746-2753. (doi:10.1007/s10620-008-0223-0)

130 Driscoll RH Jr, Meredith SC, Sitrin M \& Rosenberg IH. Vitamin D deficiency and bone disease in patients with Crohn's disease. Gastroenterology 198283 1252-1258.

131 Leichtmann GA, Bengoa JM, Bolt MJ \& Sitrin MD. Intestinal absorption of cholecalciferol and 25-hydroxycholecalciferol in patients with both Crohn's disease and intestinal resection. American Journal of Clinical Nutrition 199154 548-552.

132 Lim H, Kim HJ, Hong SJ \& Kim S. Nutrient intake and bone mineral density by nutritional status in patients with inflammatory bowel disease. Journal of Bone Metabolism 201421 195-203. (doi:10.11005/ jbm.2014.21.3.195)

133 Zittel TT, Zeeb B, Maier GW, Kaiser GW, Zwirner M, Liebich H, Starlinger M \& Becker HD. High prevalence of bone disorders after gastrectomy. American Journal of Surgery $1997 \mathbf{1 7 4} 431-438$. (doi:10.1016/S0002-9610(97)00123-2)

134 Faje AT, Karim L, Taylor A, Lee H, Miller KK, Mendes N, Meenaghan E, Goldstein MA, Bouxsein ML, Misra M et al. Adolescent girls with anorexia nervosa have impaired cortical and trabecular microarchitecture and lower estimated bone strength at the distal radius. 
Journal of Clinical Endocrinology and Metabolism 201398 1923-1929. (doi:10.1210/jc.2012-4153)

135 Misra M \& Klibanski A. Anorexia nervosa and bone. Journal of Endocrinology 2014221 R163-R176. (doi:10.1530/JOE-14-0039)

136 Valenti L, Varenna M, Fracanzani AL, Rossi V, Fargion S \& Sinigaglia L. Association between iron overload and osteoporosis in patients with hereditary hemochromatosis. Osteoporosis International 200920 549-555. (doi:10.1007/s00198-008-0701-4)

137 Guggenbuhl P, Brissot P \& Loreal O. Miscellaneous non-inflammatory musculoskeletal conditions. Haemochromatosis: the bone and the joint. Best Practice \& Research. Clinical Rheumatology 201125 649-664. (doi:10.1016/j.berh.2011.10.014)

138 Gatta A, Verardo A, Di Pascoli M, Giannini S \& Bolognesi M. Hepatic osteodystrophy. Clinical Cases in Mineral and Bone Metabolism 201411 185-191.

139 Carey EJ, Balan V, Kremers WK \& Hay JE. Osteopenia and osteoporosis in patients with end-stage liver disease caused by hepatitis $\mathrm{C}$ and alcoholic liver disease: not just a cholestatic problem. Liver Transplantation 20039 1166-1173. (doi:10.1053/jlts.2003.50242)

140 Pares A \& Guanabens N. Osteoporosis in primary biliary cirrhosis: pathogenesis and treatment. Clinics in Liver Disease 200812 407-424, x. (doi:10.1016/j.cld.2008.02.005)

141 Guanabens N, Cerda D, Monegal A, Pons F, Caballeria L, Peris P \& Pares A. Low bone mass and severity of cholestasis affect fracture risk in patients with primary biliary cirrhosis. Gastroenterology 2010138 2348-2356. (doi:10.1053/j.gastro.2010.02.016)

142 Guanabens N, Pares A, Ros I, Alvarez L, Pons F, Caballeria L, Monegal A, Martinez de Osaba MJ, Roca M, Peris P et al. Alendronate is more effective than etidronate for increasing bone mass in osteopenic patients with primary biliary cirrhosis. American Journal of Gastroenterology 200398 2268-2274. (doi:10.1111/j.1572-0241.2003.07639.x)

143 Zein CO, Jorgensen RA, Clarke B, Wenger DE, Keach JC, Angulo P \& Lindor $\mathrm{KD}$. Alendronate improves bone mineral density in primary biliary cirrhosis: a randomized placebo-controlled trial. Hepatology 200542 762-771. (doi:10.1002/hep.20866)

144 Guanabens N, Monegal A, Cerda D, Muxi A, Gifre L, Peris P \& Pares A. Randomized trial comparing monthly ibandronate and weekly alendronate for osteoporosis in patients with primary biliary cirrhosis. Hepatology 201358 2070-2078. (doi:10.1002/hep.26466)

145 Freeman AJ, Dore GJ, Law MG, Thorpe M, Von Overbeck J, Lloyd AR, Marinos G \& Kaldor JM. Estimating progression to cirrhosis in chronic hepatitis C virus infection. Hepatology 200134 809-816. (doi:10.1053/ jhep.2001.27831)

146 Lai JC, Shoback DM, Zipperstein J, Lizaola B, Tseng S \& Terrault NA. Bone mineral density, bone turnover, and systemic inflammation in noncirrhotics with chronic hepatitis C. Digestive Diseases and Sciences 2015 60 1813-1819. (doi:10.1007/s10620-014-3507-6)

147 Orsini LG, Pinheiro MM, Castro CH, Silva AE \& Szejnfeld VL. Bone mineral density measurements, bone markers and serum vitamin $\mathrm{D}$ concentrations in men with chronic non-cirrhotic untreated hepatitis C. PLoS ONE 20138 e81652. (doi:10.1371/journal.pone.0081652)

148 Pelazas-Gonzalez R, Gonzalez-Reimers E, Aleman-Valls MR, Santolaria-Fernandez F, Lopez-Prieto J, Gonzalez-Diaz A, Gomez-Sirvent JL $\&$ de la Vega-Prieto MJ. Bone alterations in hepatitis $\mathrm{C}$ virus infected patients. European Journal of Internal Medicine 201324 92-96. (doi:10.1016/j.ejim.2012.09.007)

149 Maalouf NM, Zhang S, Drechsler H, Brown GR, Tebas P \& Bedimo R. Hepatitis $\mathrm{C}$ co-infection and severity of liver disease as risk factors for osteoporotic fractures among HIV-infected patients. Journal of Bone and Mineral Research 201328 2577-2583. (doi:10.1002/jbmr.1988)

150 International Myeloma Working G. Criteria for the classification of monoclonal gammopathies, multiple myeloma and related disorders: a report of the International Myeloma Working Group. British Journal of Haematology 2003121 749-757. (doi:10.1046/j.1365-2141.2003.04355.x)

151 Melton LJ III, Rajkumar SV, Khosla S, Achenbach SJ, Oberg AL \& Kyle RA. Fracture risk in monoclonal gammopathy of undetermined significance. Journal of Bone and Mineral Research 200419 25-30. (doi:10.1359/jbmr.0301212)

152 Bida JP, Kyle RA, Therneau TM, Melton LJ III, Plevak MF, Larson DR, Dispenzieri A, Katzmann JA \& Rajkumar SV. Disease associations with monoclonal gammopathy of undetermined significance: a population-based study of 17,398 patients. Mayo Clinic Proceedings 200984 685-693. (doi:10.4065/84.8.685)

153 Melton LJ III, Kyle RA, Achenbach SJ, Oberg AL \& Rajkumar SV. Fracture risk with multiple myeloma: a population-based study. Journal of Bone and Mineral Research 200520 487-493. (doi:10.1359/ JBMR.041131)

154 Kristinsson SY, Tang M, Pfeiffer RM, Bjorkholm M, Blimark C, Mellqvist UH, Wahlin A, Turesson I \& Landgren O. Monoclonal gammopathy of undetermined significance and risk of skeletal fractures: a population-based study. Blood 2010116 2651-2655. (doi:10.1182/blood-2010-04-282848)

155 Edwards BJ, Langman CB, Bunta AD, Vicuna M \& Favus M. Secondary contributors to bone loss in osteoporosis related hip fractures. Osteoporosis International 200819 991-999. (doi:10.1007/s00198-0070525-7)

156 Kristensen IB, Christensen JH, Lyng MB, Moller MB, Pedersen L, Rasmussen LM, Ditzel HJ \& Abildgaard N. Expression of osteoblast and osteoclast regulatory genes in the bone marrow microenvironment in multiple myeloma: only up-regulation of Wnt inhibitors SFRP3 and DKK1 is associated with lytic bone disease. Leukemia \& Lymphoma 201455 911-919. (doi:10.3109/10428194.2013.820288)

157 Giuliani N, Morandi F, Tagliaferri S, Lazzaretti M, Donofrio G, Bonomini S, Sala R, Mangoni M \& Rizzoli V. Production of Wnt inhibitors by myeloma cells: potential effects on canonical Wnt pathway in the bone microenvironment. Cancer Research 200767 7665-7674. (doi:10.1158/0008-5472.CAN-06-4666)

158 Oshima T, Abe M, Asano J, Hara T, Kitazoe K, Sekimoto E, Tanaka Y, Shibata H, Hashimoto T, Ozaki S et al. Myeloma cells suppress bone formation by secreting a soluble Wnt inhibitor, sFRP-2. Blood 2005 106 3160-3165. (doi:10.1182/blood-2004-12-4940)

159 Tian E, Zhan F, Walker R, Rasmussen E, Ma Y, Barlogie B \& Shaughnessy JD Jr. The role of the Wnt-signaling antagonist DKK1 in the development of osteolytic lesions in multiple myeloma. New England Journal of Medicine 2003349 2483-2494. (doi:10.1056/ NEJMoa030847)

160 Terpos E, Christoulas D, Katodritou E, Bratengeier C, Gkotzamanidou M, Michalis E, Delimpasi S, Pouli A, Meletis J, Kastritis E et al. Elevated circulating sclerostin correlates with advanced disease features and abnormal bone remodeling in symptomatic myeloma: reduction post-bortezomib monotherapy. International Journal of Cancer 2012131 1466-1471. (doi:10.1002/ijc.27342)

161 Colucci S, Brunetti G, Oranger A, Mori G, Sardone F, Specchia G, Rinaldi E, Curci P, Liso V, Passeri G et al. Myeloma cells suppress osteoblasts through sclerostin secretion. Blood Cancer Journal 20111 e27. (doi:10.1038/bcj.2011.22)

162 Drake MT. Unveiling skeletal fragility in patients diagnosed with MGUS: no longer a condition of undetermined significance? Journal of Bone and Mineral Research 201429 2529-2533. (doi:10.1002/jbmr.2387)

163 Pepe J, Petrucci MT, Mascia ML, Piemonte S, Fassino V, Romagnoli E \& Minisola S. The effects of alendronate treatment in osteoporotic patients affected by monoclonal gammopathy of undetermined significance. Calcified Tissue International 200882 418-426. (doi:10.1007/s00223-008-9145-2)

164 Berenson JR, Yellin O, Boccia RV, Flam M, Wong SF, Batuman O, Moezi MM, Woytowitz D, Duvivier H, Nassir Y et al. Zoledronic acid markedly improves bone mineral density for patients with monoclonal gammopathy of undetermined significance and bone loss. Clinical Cancer Research 200814 6289-6295. (doi:10.1158/1078-0432.CCR-08-0666)

165 Sezer O, Heider U, Zavrski I, Kuhne CA \& Hofbauer LC. RANK ligand and osteoprotegerin in myeloma bone disease. Blood 2003101 2094-2098. (doi:10.1182/blood-2002-09-2684) 
166 Terpos E, Szydlo R, Apperley JF, Hatjiharissi E, Politou M, Meletis J, Viniou N, Yataganas X, Goldman JM \& Rahemtulla A. Soluble receptor activator of nuclear factor $\kappa \mathrm{B}$ ligand-osteoprotegerin ratio predicts survival in multiple myeloma: proposal for a novel prognostic index. Blood 2003102 1064-1069. (doi:10.1182/blood-2003-02-0380)

167 Roodman GD. Novel targets for myeloma bone disease. Expert Opinion on Therapeutic Targets 200812 1377-1387. (doi:10.1517/14728222.12. 11.1377)

168 Mhaskar R, Redzepovic J, Wheatley K, Clark OA, Miladinovic B, Glasmacher A, Kumar A \& Djulbegovic B. Bisphosphonates in multiple myeloma: a network meta-analysis. Cochrane Database of Systematic Reviews 20125 CD003188. (doi:10.1002/14651858.CD003188.pub3)

169 Hageman K, Patel KC, Mace K \& Cooper MR. The role of denosumab for prevention of skeletal-related complications in multiple myeloma. Annals of Pharmacotherapy 201347 1069-1074. (doi:10.1345/aph.1R776)

170 Brumsen C, Papapoulos SE, Lentjes EG, Kluin PM \& Hamdy NA. A potential role for the mast cell in the pathogenesis of idiopathic osteoporosis in men. Bone 200231 556-561. (doi:10.1016/S87563282(02)00875-X)

171 Rossini M, Zanotti R, Bonadonna P, Artuso A, Caruso B, Schena D, Vecchiato D, Bonifacio M, Viapiana O, Gatti D et al. Bone mineral density, bone turnover markers and fractures in patients with indolent systemic mastocytosis. Bone 201149 880-885. (doi:10.1016/ j.bone.2011.07.004)

172 von Bubnoff N, Gorantla SH, Kancha RK, Lordick F, Peschel C \& Duyster J. The systemic mastocytosis-specific activating cKit mutation D816V can be inhibited by the tyrosine kinase inhibitor AMN107. Leukemia 200519 1670-1671. (doi:10.1038/sj.leu.2403887)

173 Theoharides TC, Boucher W \& Spear K. Serum interleukin-6 reflects disease severity and osteoporosis in mastocytosis patients. International Archives of Allergy and Immunology 2002128 344-350. (doi:10.1159/000063858)

174 Rabenhorst A, Christopeit B, Leja S, Gerbaulet A, Kleiner S, Forster A, Raap U, Wickenhauser C \& Hartmann K. Serum levels of bone cytokines are increased in indolent systemic mastocytosis associated with osteopenia or osteoporosis. Journal of Allergy and Clinical Immunology 2013132 1234-1237.e7. (doi:10.1016/j.jaci.2013.06.019)

175 Marshall A, Kavanagh RT \& Crisp AJ. The effect of pamidronate on lumbar spine bone density and pain in osteoporosis secondary to systemic mastocytosis. British Journal of Rheumatology 199736 393-396. (doi:10.1093/rheumatology/36.3.393)

176 Rossini M, Zanotti R, Viapiana O, Tripi G, Idolazzi L, Biondan M, Orsolini G, Bonadonna P, Adami S \& Gatti D. Zoledronic acid in osteoporosis secondary to mastocytosis. American Journal of Medicine 2014127 1127.e1-4. (doi:10.1016/j.amjmed.2014.06.015)

177 Haidar R, Musallam KM \& Taher AT. Bone disease and skeletal complications in patients with $\beta$ thalassemia major. Bone 201148 425-432. (doi:10.1016/j.bone.2010.10.173)

178 Giusti A. Bisphosphonates in the management of thalassemiaassociated osteoporosis: a systematic review of randomised controlled trials. Journal of Bone and Mineral Metabolism 201432 606-615. (doi:10.1007/s00774-014-0584-8)

179 Lauderdale DS, Thisted RA, Wen M \& Favus MJ. Bone mineral density and fracture among prevalent kidney stone cases in the Third National Health and Nutrition Examination Survey. Journal of Bone and Mineral Research 200116 1893-1898. (doi:10.1359/jbmr.2001.16.10.1893)

180 Heilberg IP \& Weisinger JR. Bone disease in idiopathic hypercalciuria. Current Opinion in Nephrology and Hypertension 200615 394-402. (doi:10.1097/01.mnh.0000232880.58340.0c)

181 Urivetzky M, Anna PS \& Smith AD. Plasma osteocalcin levels in stone disease. A potential aid in the differential diagnosis of calcium nephrolithiasis. Journal of Urology 1988139 12-14.

182 Weisinger JR, Alonzo E, Bellorin-Font E, Blasini AM, Rodriguez MA, Paz-Martinez V \& Martinis R. Possible role of cytokines on the bone mineral loss in idiopathic hypercalciuria. Kidney International 199649 244-250. (doi:10.1038/ki.1996.34)
183 Coe FL, Favus MJ, Crockett T, Strauss AL, Parks JH, Porat A, Gantt CL \& Sherwood LM. Effects of low-calcium diet on urine calcium excretion, parathyroid function and serum 1,25(OH)2D3 levels in patients with idiopathic hypercalciuria and in normal subjects. American Journal of Medicine 198272 25-32. (doi:10.1016/0002-9343(82)90567-8)

184 Favus MJ, Karnauskas AJ, Parks JH \& Coe FL. Peripheral blood monocyte vitamin $\mathrm{D}$ receptor levels are elevated in patients with idiopathic hypercalciuria. Journal of Clinical Endocrinology and Metabolism 200489 4937-4943. (doi:10.1210/jc.2004-0412)

185 Krieger NS \& Bushinsky DA. The relation between bone and stone formation. Calcified Tissue International 201393 374-381. (doi:10.1007/s00223-012-9686-2)

186 Friedman PA \& Bushinsky DA. Diuretic effects on calcium metabolism. Seminars in Nephrology 199919 551-556.

187 Coe FL, Parks JH, Bushinsky DA, Langman CB \& Favus MJ. Chlorthalidone promotes mineral retention in patients with idiopathic hypercalciuria. Kidney International 198833 1140-1146. (doi:10.1038/ki.1988.122)

188 Breslau N, Moses AM \& Weiner IM. The role of volume contraction in the hypocalciuric action of chlorothiazide. Kidney International 1976 10 164-170. (doi:10.1038/ki.1976.91)

189 Dvorak MM, De Joussineau C, Carter DH, Pisitkun T, Knepper MA, Gamba G, Kemp PJ \& Riccardi D. Thiazide diuretics directly induce osteoblast differentiation and mineralized nodule formation by interacting with a sodium chloride co-transporter in bone. Journal of the American Society of Nephrology 200718 2509-2516. (doi:10.1681/ ASN.2007030348)

190 Pearle MS, Roehrborn CG \& Pak CY. Meta-analysis of randomized trials for medical prevention of calcium oxalate nephrolithiasis. Journal of Endourology 199913 679-685. (doi:10.1089/end.1999.13.679)

191 Rejnmark L, Vestergaard P \& Mosekilde L. Reduced fracture risk in users of thiazide diuretics. Calcified Tissue International $2005 \mathbf{7 6}$ 167-175. (doi:10.1007/s00223-004-0084-2)

192 Feskanich D, Willett WC, Stampfer MJ \& Colditz GA. A prospective study of thiazide use and fractures in women. Osteoporosis International 19977 79-84. (doi:10.1007/BF01623465)

193 Sigurdsson G \& Franzson L. Increased bone mineral density in a population-based group of 70-year-old women on thiazide diuretics, independent of parathyroid hormone levels. Journal of Internal Medicine 2001250 51-56. (doi:10.1046/j.1365-2796.2001.00850.x)

194 Hall TJ \& Schaueblin M. Hydrochlorothiazide inhibits osteoclastic bone resorption in vitro. Calcified Tissue International 199455 266-268. (doi:10.1007/BF00310404)

195 Lalande A, Roux S, Denne MA, Stanley ER, Schiavi P, Guez D \& De Vernejoul MC. Indapamide, a thiazide-like diuretic, decreases bone resorption in vitro. Journal of Bone and Mineral Research 200116 361-370. (doi:10.1359/jbmr.2001.16.2.361)

196 Krieger NS, Frick KK \& Bushinsky DA. Mechanism of acid-induced bone resorption. Current Opinion in Nephrology and Hypertension 2004 13 423-436. (doi:10.1097/01.mnh.0000133975.32559.6b)

197 Green J \& Kleeman CR. Role of bone in regulation of systemic acid-base balance. Kidney International 199139 9-26. (doi:10.1038/ki.1991.2)

198 Weger M, Deutschmann H, Weger W, Kotanko P \& Skrabal F. Incomplete renal tubular acidosis in 'primary' osteoporosis. Osteoporosis International 199910 325-329. (doi:10.1007/s001980050235)

199 Frick KK, LaPlante K \& Bushinsky DA. RANK ligand and TNF- $\alpha$ mediate acid-induced bone calcium efflux in vitro. American Journal of Physiology. Renal Physiology 2005289 F1005-F1011. (doi:10.1152/ ajprenal.00420.2004)

200 Jamal SA, West SL \& Miller PD. Fracture risk assessment in patients with chronic kidney disease. Osteoporosis International 201223 1191-1198. (doi:10.1007/s00198-011-1781-0)

201 Sakhaee K \& Gonzalez GB. Update on renal osteodystrophy: pathogenesis and clinical management. American Journal of Medical Sciences 1999317 251-260. (doi:10.1097/00000441-19990400000008) 
202 Miller PD. Bone disease in CKD: a focus on osteoporosis diagnosis and management. American Journal of Kidney Diseases 201464 290-304. (doi:10.1053/j.ajkd.2013.12.018)

203 Huusko TM, Korpela M, Karppi P, Avikainen V, Kautiainen H \& Sulkava R. Threefold increased risk of hip fractures with rheumatoid arthritis in Central Finland. Annals of the Rheumatic Diseases 200160 521-522. (doi:10.1136/ard.60.5.521)

204 Brennan SL, Toomey L, Kotowicz MA, Henry MJ, Griffiths H \& Pasco JA. Rheumatoid arthritis and incident fracture in women: a case-control study. BMC Musculoskeletal Disorders 20141513. (doi:10.1186/1471-2474-15-13)

205 Geusens PP, Landewe RB, Garnero P, Chen D, Dunstan CR, Lems WF, Stinissen P, van der Heijde DM, van der Linden S \& Boers M. The ratio of circulating osteoprotegerin to RANKL in early rheumatoid arthritis predicts later joint destruction. Arthritis and Rheumatism $2006 \mathbf{5 4}$ 1772-1777. (doi:10.1002/art.21896)

206 Vis M, Havaardsholm EA, Haugeberg G, Uhlig T, Voskuyl AE, van de Stadt RJ, Dijkmans BA, Woolf AD, Kvien TK \& Lems WF. Evaluation of bone mineral density, bone metabolism, osteoprotegerin and receptor activator of the NFאB ligand serum levels during treatment with infliximab in patients with rheumatoid arthritis. Annals of the Rheumatic Diseases 200665 1495-1499. (doi:10.1136/ard.2005. 044198)

207 Miao CG, Yang YY, He X, Li XF, Huang C, Huang Y, Zhang L, Lv XW, Jin Y \& Li J. Wnt signaling pathway in rheumatoid arthritis, with special emphasis on the different roles in synovial inflammation and bone remodeling. Cellular Signalling 201325 2069-2078. (doi:10.1016/j.cellsig.2013.04.002)

208 Terpos E, Fragiadaki K, Konsta M, Bratengeier C, Papatheodorou A \& Sfikakis PP. Early effects of IL-6 receptor inhibition on bone homeostasis: a pilot study in women with rheumatoid arthritis. Clinical and Experimental Rheumatology 201129 921-925.

209 Ross DW. Differences in cell cycle kinetics during induced granulocytic versus monocytic maturation of HL-60 leukemia cells. Cancer Research 198545 1308-1313.

210 Yee CS, Crabtree N, Skan J, Amft N, Bowman S, Situnayake D \& Gordon C. Prevalence and predictors of fragility fractures in systemic lupus erythematosus. Annals of the Rheumatic Diseases 200564 111-113. (doi:10.1136/ard.2003.018127)

211 Kipen Y, Buchbinder R, Forbes A, Strauss B, Littlejohn G \& Morand E. Prevalence of reduced bone mineral density in systemic lupus erythematosus and the role of steroids. Journal of Rheumatology 1997 24 1922-1929.

212 Borba VZ, Vieira JG, Kasamatsu T, Radominski SC, Sato EI \& Lazaretti-Castro M. Vitamin D deficiency in patients with active systemic lupus erythematosus. Osteoporosis International 200920 427-433. (doi:10.1007/s00198-008-0676-1)

213 Prieto-Alhambra D, Munoz-Ortego J, De Vries F, Vosse D, Arden NK, Bowness P, Cooper C, Diez-Perez A \& Vestergaard P. Ankylosing spondylitis confers substantially increased risk of clinical spine fractures: a nationwide case-control study. Osteoporosis International 201426 85-91. (doi:10.1007/s00198-014-2939-3)

214 Nigil Haroon N, Sriganthan J, Al Ghanim N, Inman RD \& Cheung AM. Effect of TNF- $\alpha$ inhibitor treatment on bone mineral density in patients with ankylosing spondylitis: A systematic review and metaanalysis. Seminars in Arthritis and Rheumatism 201444 155-161. (doi:10.1016/j.semarthrit.2014.05.008)

215 Weinstock-Guttman B, Gallagher E, Baier M, Green L, Feichter J, Patrick K, Miller C, Wrest K \& Ramanathan M. Risk of bone loss in men with multiple sclerosis. Multiple Sclerosis 200410 170-175. (doi:10.1191/1352458504ms993oa)

216 Dennison EM, Compston JE, Flahive J, Siris ES, Gehlbach SH, Adachi JD, Boonen S, Chapurlat R, Diez-Perez A, Anderson FA Jr et al. Effect of co-morbidities on fracture risk: findings from the Global Longitudinal Study of Osteoporosis in Women (GLOW). Bone 201250 1288-1293. (doi:10.1016/j.bone.2012.02.639)
217 Sioka C, Fotopoulos A, Georgiou A, Papakonstantinou S, Pelidou SH, Kyritsis AP \& Kalef-Ezra JA. Body composition in ambulatory patients with multiple sclerosis. Journal of Clinical Densitometry $2011 \mathbf{1 4}$ 465-470. (doi:10.1016/j.jocd.2011.04.012)

218 Gibson JC \& Summers GD. Bone health in multiple sclerosis. Osteoporosis International 201122 2935-2949. (doi:10.1007/ s00198-011-1644-8)

219 Eom CS, Lee HK, Ye S, Park SM \& Cho KH. Use of selective serotonin reuptake inhibitors and risk of fracture: a systematic review and metaanalysis. Journal of Bone and Mineral Research 201227 1186-1195. (doi:10.1002/jbmr.1554)

220 Moura C, Bernatsky S, Abrahamowicz M, Papaioannou A, Bessette L, Adachi J, Goltzman D, Prior J, Kreiger N, Towheed T et al. Antidepressant use and 10-year incident fracture risk: the populationbased Canadian Multicentre Osteoporosis Study (CaMoS). Osteoporosis International 201425 1473-1481. (doi:10.1007/s00198-014-2649-x)

221 Shea ML, Garfield LD, Teitelbaum S, Civitelli R, Mulsant BH, Reynolds CF III, Dixon D, Dore P \& Lenze EJ. Serotonin-norepinephrine reuptake inhibitor therapy in late-life depression is associated with increased marker of bone resorption. Osteoporosis International 201324 1741-1749. (doi:10.1007/s00198-012-2170-z)

222 Sheth RD, Gidal BE \& Hermann BP. Pathological fractures in epilepsy. Epilepsy \& Behavior 20069 601-605. (doi:10.1016/j.yebeh. 2006.08.003)

223 Ensrud KE, Walczak TS, Blackwell T, Ensrud ER, Bowman PJ \& Stone KL. Antiepileptic drug use increases rates of bone loss in older women: a prospective study. Neurology 200462 2051-2057. (doi:10.1212/01.WNL.0000125185.74276.D2)

224 Vestergaard P, Tigaran S, Rejnmark L, Tigaran C, Dam M \& Mosekilde L. Fracture risk is increased in epilepsy. Acta Neurologica Scandinavica 199999 269-275. (doi:10.1111/j.1600-0404.1999. tb00675.x)

225 Fitzpatrick LA. Pathophysiology of bone loss in patients receiving anticonvulsant therapy. Epilepsy \& Behavior 20045 (Suppl 2) S3-S15. (doi:10.1016/j.yebeh.2003.11.026)

226 Petty SJ, O'Brien TJ \& Wark JD. Anti-epileptic medication and bone health. Osteoporosis International 200718 129-142. (doi:10.1007/ s00198-006-0185-z)

227 Anderson GD \& Hakimian S. Pharmacokinetic of antiepileptic drugs in patients with hepatic or renal impairment. Clinical Pharmacokinetics 201453 29-49. (doi:10.1007/s40262-013-0107-0)

228 Shen C, Chen F, Zhang Y, Guo Y \& Ding M. Association between use of antiepileptic drugs and fracture risk: a systematic review and metaanalysis. Bone 201464 246-253. (doi:10.1016/j.bone.2014.04.018)

229 Jones G, Prosser DE \& Kaufmann M. Cytochrome P450-mediated metabolism of vitamin D. Journal of Lipid Research 201455 13-31. (doi:10.1194/jlr.R031534)

230 Lazzari AA, Dussault PM, Thakore-James M, Gagnon D, Baker E, Davis SA \& Houranieh AM. Prevention of bone loss and vertebral fractures in patients with chronic epilepsy-antiepileptic drug and osteoporosis prevention trial. Epilepsia 201354 1997-2004. (doi:10.1111/epi.12351)

231 Fraser LA, Adachi JD, Leslie WD, Goltzman D, Josse R, Prior J, Kaiser S, Kreiger N, Kovacs CS, Anastassiades TP et al. Effect of anticholinergic medications on falls, fracture risk, and bone mineral density over a 10-year period. Annals of Pharmacotherapy 201448 954-961. (doi:10.1177/1060028014535363)

232 Leidig-Bruckner G, Hosch S, Dodidou P, Ritschel D, Conradt C, Klose C, Otto G, Lange R, Theilmann L, Zimmerman R et al. Frequency and predictors of osteoporotic fractures after cardiac or liver transplantation: a follow-up study. Lancet 2001357 342-347. (doi:10.1016/S0140-6736(00)03641-2)

233 Orcel P, Denne MA \& de Vernejoul MC. Cyclosporin-A in vitro decreases bone resorption, osteoclast formation, and the fusion of cells of the monocyte-macrophage lineage. Endocrinology 1991128 1638-1646. (doi:10.1210/endo-128-3-1638) 
234 Sun L, Blair HC, Peng Y, Zaidi N, Adebanjo OA, Wu XB, Wu XY, Iqbal J, Epstein S, Abe $\mathrm{E}$ et al. Calcineurin regulates bone formation by the osteoblast. PNAS 2005102 17130-17135. (doi:10.1073/pnas.0508480102)

235 Yeo H, Beck LH, Thompson SR, Farach-Carson MC, McDonald JM, Clemens TL \& Zayzafoon M. Conditional disruption of calcineurin B1 in osteoblasts increases bone formation and reduces bone resorption. Journal of Biological Chemistry 2007282 35318-35327. (doi:10.1074/ jbc.M702435200)

236 Takayanagi H, Kim S, Koga T, Nishina H, Isshiki M, Yoshida H, Saiura A, Isobe M, Yokochi T, Inoue J et al. Induction and activation of the transcription factor NFATc1 (NFAT2) integrate RANKL signaling in terminal differentiation of osteoclasts. Developmental Cell 20023 889-901. (doi:10.1016/S1534-5807(02)00369-6)

237 Zanotti S, Smerdel-Ramoya A \& Canalis E. Reciprocal regulation of Notch and nuclear factor of activated T-cells (NFAT)c1 transactivation in osteoblasts. Journal of Biological Chemistry 2011286 4576-4588. (doi:10.1074/jbc.M110.161893)

238 Zanotti S, Smerdel-Ramoya A \& Canalis E. Nuclear factor of activated T-cells (Nfat)c2 inhibits Notch signaling in osteoblasts. Journal of Biological Chemistry 2013288 624-632. (doi:10.1074/jbc.M112.340455)

239 Krol CG, Dekkers OM, Kroon HM, Rabelink TJ, van Hoek B \& Hamdy NA. No association between BMD and prevalent vertebral fractures in liver transplant recipients at time of screening before transplantation. Journal of Clinical Endocrinology and Metabolism 2014 99 3677-3685. (doi:10.1210/jc.2014-1469)

240 Ebeling PR. Approach to the patient with transplantation-related bone loss. Journal of Clinical Endocrinology and Metabolism 200994 1483-1490. (doi:10.1210/jc.2009-0205)

241 Triant VA, Brown TT, Lee H \& Grinspoon SK. Fracture prevalence among human immunodeficiency virus (HIV)-infected versus nonHIV-infected patients in a large U.S. healthcare system. Journal of Clinical Endocrinology and Metabolism 200893 3499-3504. (doi:10.1210/jc.2008-0828)

242 Shiau S, Broun EC, Arpadi SM \& Yin MT. Incident fractures in HIVinfected individuals: a systematic review and meta-analysis. AIDS 201327 1949-1957. (doi:10.1097/QAD.0b013e328361d241)

243 Pan G, Yang Z, Ballinger SW \& McDonald JM. Pathogenesis of osteopenia/osteoporosis induced by highly active anti-retroviral therapy for AIDS. Annals of the New York Academy of Sciences 20061068 297-308. (doi:10.1196/annals.1346.057)

244 Muir JM, Andrew M, Hirsh J, Weitz JI, Young E, Deschamps P \& Shaughnessy SG. Histomorphometric analysis of the effects of standard heparin on trabecular bone in vivo. Blood 1996 88 1314-1320.

245 Rajgopal R, Bear M, Butcher MK \& Shaughnessy SG. The effects of heparin and low molecular weight heparins on bone. Thrombosis Research 2008122 293-298. (doi:10.1016/j.thromres.2006.10.025)

246 Irie A, Takami M, Kubo H, Sekino-Suzuki N, Kasahara K \& Sanai Y. Heparin enhances osteoclastic bone resorption by inhibiting osteoprotegerin activity. Bone 200741 165-174. (doi:10.1016/j.bone.2007.04.190)

247 Dahlman TC. Osteoporotic fractures and the recurrence of thromboembolism during pregnancy and the puerperium in 184 women undergoing thromboprophylaxis with heparin. American Journal of Obstetrics and Gynecology 1993168 1265-1270. (doi:10.1016/00029378(93)90378-V)

248 Douketis JD, Ginsberg JS, Burrows RF, Duku EK, Webber CE \& Brill-Edwards $P$. The effects of long-term heparin therapy during pregnancy on bone density. A prospective matched cohort study. Thrombosis and Haemostasis $1996 \mathbf{7 5}$ 254-257.

249 Monreal M, Lafoz E, Olive A, del Rio L \& Vedia C. Comparison of subcutaneous unfractionated heparin with a low molecular weight heparin (Fragmin) in patients with venous thromboembolism and contraindications to coumarin. Thrombosis and Haemostasis 1994 71 7-11.

250 Price PA \& Williamson MK. Effects of warfarin on bone. Studies on the vitamin K-dependent protein of rat bone. Journal of Biochemistry 1981 256 12754-12759.

251 Jamal SA, Browner WS, Bauer DC \& Cummings SR. Warfarin use and risk for osteoporosis in elderly women. Study of Osteoporotic Fractures Research Group. Annals of Internal Medicine 1998128 829-832. (doi:10.7326/0003-4819-128-10-199805150-00006)

252 Woo C, Chang LL, Ewing SK, Bauer DC \& Osteoporotic Fractures in Men Study G. Single-point assessment of warfarin use and risk of osteoporosis in elderly men. Journal of the American Geriatrics Society 200856 1171-1176. (doi:10.1111/j.1532-5415.2008.01786.x)

253 van Diepen S, Majumdar SR, Bakal JA, McAlister FA \& Ezekowitz JA. Heart failure is a risk factor for orthopedic fracture: a population-based analysis of 16,294 patients. Circulation 2008118 1946-1952. (doi:10.1161/CIRCULATIONAHA.108.784009)

254 Rejnmark L, Vestergaard P, Heickendorff L, Andreasen F \& Mosekilde L. Loop diuretics increase bone turnover and decrease BMD in osteopenic postmenopausal women: results from a randomized controlled study with bumetanide. Journal of Bone and Mineral Research 200621 163-170. (doi:10.1359/JBMR.051003)

255 Carbone LD, Johnson KC, Bush AJ, Robbins J, Larson JC, Thomas A \& LaCroix AZ. Loop diuretic use and fracture in postmenopausal women: findings from the Women's Health Initiative. Archives of Internal Medicine 2009169 132-140. (doi:10.1001/archinternmed.2008.526)

256 Lim LS, Fink HA, Kuskowski MA, Taylor BC, Schousboe JT, Ensrud KE $\&$ Osteoporotic Fractures in Men Study G. Loop diuretic use and increased rates of hip bone loss in older men: the Osteoporotic Fractures in Men Study. Archives of Internal Medicine 2008168 735-740. (doi:10.1001/archinte.168.7.735)

257 Cauley JA, Cummings SR, Seeley DG, Black D, Browner W, Kuller LH \& Nevitt MC. Effects of thiazide diuretic therapy on bone mass, fractures, and falls. The Study of Osteoporotic Fractures Research Group. Annals of Internal Medicine 1993118 666-673. (doi:10.7326/00034819-118-9-199305010-00002)

258 Solomon DH, Diem SJ, Ruppert K, Lian Y, Liu CC, Wohlfart A, Greendale GA \& Finkelstein JS. Bone mineral density changes among women initiating proton pump inhibitors or $\mathrm{H} 2$ receptor antagonists: a SWAN cohort study. Journal of Bone and Mineral Research 201430 232-239. (doi:10.1002/jbmr.2344)

259 Fraser LA, Leslie WD, Targownik LE, Papaioannou A, AdachiJD \& CaMos Research G . The effect of proton pump inhibitors on fracture risk: report from the Canadian Multicenter Osteoporosis Study. Osteoporosis International 201324 1161-1168. (doi:10.1007/s00198-012-2112-9)

260 Gray SL, LaCroix AZ, Larson J, Robbins J, Cauley JA, Manson JE \& Chen Z. Proton pump inhibitor use, hip fracture, and change in bone mineral density in postmenopausal women: results from the Women's Health Initiative. Archives of Internal Medicine 2010170 765-771. (doi:10.1001/archinternmed.2010.94)

261 Targownik LE, Lix LM, Metge CJ, Prior HJ, Leung S \& Leslie WD. Use of proton pump inhibitors and risk of osteoporosis-related fractures. CMAJ: Canadian Medical Association Journal 2008179 319-326. (doi:10.1503/cmaj.071330)

262 de Klerk G, Hegeman JH, van der Velde D, van der Palen J, van Bergeijk L \& Duis HJ. The value of laboratory tests in diagnosing secondary osteoporosis at a fracture and osteoporosis outpatient clinic. Geriatric Orthopaedic Surgery \& Rehabilitation 20134 53-57. (doi:10.1177/2151458513501176)

Received 30 January 2015

Revised version received 5 May 2015

Accepted 12 May 2015 